\title{
Lipocalin-2 Is an Autocrine Mediator of Reactive Astrocytosis
}

\author{
Shinrye Lee, ${ }^{1}$ Jae-Yong Park, ${ }^{2}$ Won-Ha Lee, ${ }^{3}$ Ho Kim, ${ }^{4}$ Hae-Chul Park, ${ }^{4}$ Kiyoshi Mori, ${ }^{5}$ and Kyoungho Suk ${ }^{1}$ \\ ${ }^{1}$ Department of Pharmacology, Brain Science and Engineering Institute, Cell Matrix Research Institute, Kyungpook National University School of Medicine, \\ Daegu 700-422, Korea, 2Department of Physiology, Gyeongsang National University College of Medicine, Jinju 660-751, Korea, ${ }^{3}$ Department of Genetic \\ Engineering, College of Natural Sciences, Kyungpook National University, Daegu 702-701, Korea, ${ }^{4}$ Department of Medical Science, Korea University Ansan \\ Hospital, Ansan, Gyeonggi-do 425-707, Korea, and 5 Department of Medicine and Clinical Science, Kyoto University Graduate School of Medicine, Kyoto \\ 606-8507, Japan
}

Astrocytes, the most abundant glial cell type in the brain, provide metabolic and trophic support to neurons and modulate synaptic activity. In response to a brain injury, astrocytes proliferate and become hypertrophic with an increased expression of intermediate filament proteins. This process is collectively referred to as reactive astrocytosis. Lipocalin $2(\mathrm{lcn} 2)$ is a member of the lipocalin family that binds to small hydrophobic molecules. We propose that $\operatorname{lcn} 2$ is an autocrine mediator of reactive astrocytosis based on the multiple roles of $1 \mathrm{cn} 2$ in the regulation of cell death, morphology, and migration of astrocytes. lcn2 expression and secretion increased after inflammatory stimulation in cultured astrocytes. Forced expression of lcn 2 or treatment with LCN2 protein increased the sensitivity of astrocytes to cytotoxic stimuli. Iron and BIM (Bcl-2-interacting mediator of cell death) proteins were involved in the cytotoxic sensitization process. LCN2 protein induced upregulation of glial fibrillary acidic protein (GFAP), cell migration, and morphological changes similar to characteristic phenotypic changes termed reactive astrocytosis. The lcn2-induced phenotypic changes of astrocytes occurred through a Rho-ROCK (Rho kinase)-GFAP pathway, which was positively regulated by nitric oxide and cGMP. In zebrafishes, forced expression of rat lcn2 gene increased the number and thickness of cellular processes in GFAP-expressing radial glia cells, suggesting that lcn2 expression in glia cells plays an important role in vivo. Our results suggest that lcn 2 acts in an autocrine manner to induce cell death sensitization and morphological changes in astrocytes under inflammatory conditions and that these phenotypic changes may be the basis of reactive astrocytosis in vivo.

Key words: astrocyte; astrocytosis; glial fibrillary acidic protein; lipocalin 2; neuroinflammation; zebrafish

\section{Introduction}

Astrocytes are the most abundant glial cell type in the brain (Aschner, 1998; Barres and Barde, 2000). Astrocytes provide metabolic and trophic support to neurons and modulate synaptic activity. They are also the main responders to CNS aggravations under various pathological conditions such as injury, ischemia, infection, and neurodegeneration (Farina et al., 2007). In response to all types of CNS insults, astrocytes become reactive and undergo a process termed reactive astrocytosis (Pekny and Nilsson, 2005; Sofroniew, 2005; Correa-Cerro and Mandell, 2007). In this process, astrocytes proliferate to fill gaps and undergo a typical morphological change: a large cytoplasmic mass, long and branched processes, and increased expression of intermediate filaments such as glial fibrillary acidic protein (GFAP). Although

Received Nov. 2, 2008; accepted Nov. 30, 2008.

This work was supported by Bio R\&D Program through the Korea Science and Engineering Foundation, funded by Ministry of Education, Science, and Technology Grant 2008-04090. S.L. was supported by the Brain Korea 21 Project in 2008. J.-Y.P. and K.S. are the recipients of Korea Research Foundation Grant KRF-2006-005-J04202 funded by the Korean Government (Ministry of Education and Human Resource Development, Basic Research Promotion Fund).

Correspondence should be addressed to Kyoungho Suk, Department of Pharmacology, Kyungpook National University School of Medicine, 101 Dong-In, Joong-gu, Daegu 700-422, Korea. E-mail: ksuk@knu.ac.kr.

D01:10.1523/JNEUROSCI.5273-08.2009

Copyright $\odot 2009$ Society for Neuroscience $\quad$ 0270-6474/09/290234-16\$15.00/0 the basic process of reactive astrocytosis is evolutionarily conserved and accompanies all forms of neural injuries, the precise molecular mechanisms underlying the reactive astrocytosis processes are presently far from clear.

Recent evidence indicated that inflammatory cells in the CNS may undergo apoptosis on activation in a manner similar to activation-induced cell death of lymphocytes (Mabuchi et al., 2000; P. Lee et al., 2001; Liu et al., 2001; Suk et al., 2001; Falsig et al., 2004; Suk, 2005). Microglia as well as astrocytes have been shown to undergo apoptosis on a strong inflammatory activation (Hu and Van Eldik, 1996; Ferrari et al., 1997; Kingham and Pocock, 2000; J. Lee et al., 2001; Suk et al., 2002; Takuma et al., 2004). It has been proposed that apoptosis of glia cells after massive proliferation may be a means of population control (Jones et al., 1997). However, little is known about the molecular mechanisms underlying the autoregulatory apoptosis of glia and the termination of neuroinflammation.

Lipocalin $2(\operatorname{lcn} 2)$ is a member of the lipocalin family, which binds or transports lipid and other hydrophobic molecules (Flower et al., 2000; Kjeldsen et al., 2000). lcn2 is also known as $24 \mathrm{p} 3$ and neutrophil gelatinase-associated lipocalin (NGAL) (Borregaard and Cowland, 2006). In vitro studies have shown that $1 \mathrm{cn} 2$ is important for both cellular apoptosis and survival 
(Devireddy et al., 2001, 2005; Yousefi and Simon, 2002; Tong et al., 2003, 2005; Nelson et al., 2008). It also plays an important role in the induction of cellular differentiation in kidney during embryogenesis (Yang et al., 2002) and protects the kidney from ischemic injury (Mishra et al., 2004; Mori et al., 2005). lcn2 has been proposed as the real-time indicator of active kidney damage (Mori and Nakao, 2007). lcn2-deficient mice exhibited an increased susceptibility to Escherichia coli infection because of the failure of iron sequestration, indicating a critical role of $1 \mathrm{cn} 2$ in the protection against bacterial infection (Flo et al., 2004). lcn2 may function as an acute-phase protein (Liu and NilsenHamilton, 1995) and an adipokine involved in insulin resistance (Yan et al., 2007). Recently, two cellular receptors for lcn2 have been identified, megalin (Hvidberg et al., 2005) and brain type organic cation transporter (Devireddy et al., 2005). However, the precise role of $\ln 2$ in the cell survival and death has yet to be determined.

In the present study, we investigated the role of $1 \mathrm{cn} 2$ in both functional and structural changes of reactive astrocytes. Our results indicated that $l \mathrm{cn} 2$ is critical for cell death sensitization, stimulation of cell migration, and morphological changes of reactive astrocytes. Additional studies showed that iron metabolism and Bcl-2-interacting mediator of cell death (BIM) protein are involved in the $1 \mathrm{cn} 2$-induced cytotoxic sensitization and that Rho-Rho kinase (ROCK) pathway with a positive amplification via nitric oxide/cGMP is involved in the lcn2-mediated morphological changes of reactive astrocytes. Last, the expression of lcn2 in glia cells and the role of $1 \mathrm{cn} 2$ in the phenotypic changes similar to reactive astrocytosis were confirmed in vivo using a zebrafish model.

\section{Materials and Methods}

\section{Reagents and cells}

The following chemicals were obtained from Sigma-Aldrich: lipopolysaccharide (LPS) from E. coli 0111:B4 prepared by phenolic extraction and gel filtration chromatography, sodium nitroprusside dihydrate (SNP), S-nitroso- $\mathrm{N}$-acetylpenicillamine (SNAP), phorbol 12-myristate 13-acetate (PMA), paraquat dichloride, ganglioside mixture, $\mathrm{H}_{2} \mathrm{O}_{2}, \mathrm{~N}^{\mathrm{G}}$ monomethyl-L-arginine (NMMA), forskolin, dibutyryl cyclic GMP (dbcGMP), deferoxamine mesylate, ferric citrate, and polymyxin B. A ROCK inhibitor (R)-(+)-trans- $N$-(4-pyridyl)-4-(1-aminoethyl)cyclohexanecarboxamide (Y27632) was purchased from Calbiochem. Recombinant human tumor necrosis factor $\alpha$ (TNF- $\alpha$ ) and mouse interferon- $\gamma($ IFN- $\gamma)$ proteins were purchased from R\&D Systems. Ironsaturated enterochelin $(0.7 \mathrm{kDa})$ was purchased from EMC Microcollections. All other chemicals, unless stated otherwise, were obtained from Sigma-Aldrich. C6 rat glioma cells were maintained in DMEM supplemented with $5 \%$ heat-inactivated fetal bovine serum (FBS) (Invitrogen), gentamicin $(50 \mu \mathrm{g} / \mathrm{ml})$. Astrocyte cultures were prepared from the brains of 0 - to 3-d-old ICR mice (Samtako) by the method of McCarthy and de Vellis (1980). Briefly, whole brains were dissociated in DMEM, supplemented with $10 \% \mathrm{FBS}, 100 \mathrm{U} / \mathrm{ml}$ penicillin, and $100 \mu \mathrm{g} / \mathrm{ml}$ streptomycin (Invitrogen). Cells were seeded at $75 \mathrm{~cm}^{2}$ tissue culture flasks coated with poly-D-lysine (Falcon; BD Biosciences Discovery Labware). Cells were grown at $37^{\circ} \mathrm{C}$ in a $5 \% \mathrm{CO}_{2}$ humidified atmosphere. The culture medium was changed after $5 \mathrm{~d}$ in vitro and then every $3 \mathrm{~d}$. Secondary pure cultures of astrocytes were obtained by shaking mixed glial cultures at $250 \mathrm{rpm}$ overnight, and then culture medium was discarded. Astrocytes were dissociated using trypsin-EDTA (Invitrogen) and then collected by means of centrifugation at $1000 \mathrm{rpm}$ for $10 \mathrm{~min}$. The cells were resuspended in DMEM with $10 \% \mathrm{FBS}, 100 \mathrm{U} / \mathrm{ml}$ penicillin, and $100 \mu \mathrm{g} / \mathrm{ml}$ streptomycin, seeded at $1 \times 10^{5} \mathrm{cells} / \mathrm{ml}$ onto six-well plates coated with poly-D-lysine, and cultured for $4 \mathrm{~d}$. The purity of astrocyte cultures was $>96 \%$ as determined by GFAP immunocytochemical staining. Animals used in the current research had been acquired and cared for in accordance with the guidelines published in the National Institutes of Health Guide for the Care and Use of Laboratory Animals.

\section{Assessment of cytotoxicity by MTT assay}

Cells $\left(5 \times 10^{4}\right.$ cells in $200 \mu \mathrm{l} /$ well $)$ were seeded in 96-well plates and treated with various stimuli for the specific time periods. After treatment, the medium was removed and 3-[4,5-dimethylthiazol-2-yl]-2,5diphenyltetrazolium bromide (MTT) $(0.5 \mathrm{mg} / \mathrm{ml})$ was added, followed by incubation at $37^{\circ} \mathrm{C}$ for $2 \mathrm{~h}$ in a $\mathrm{CO}_{2}$ incubator. After insoluble crystals were completely dissolved in DMSO, absorbance at $570 \mathrm{~nm}$ was measured by using a microplate reader (Anthos Labtec Instruments).

\section{Nitrite quantification}

Cells were treated with stimuli in 96-well plates, and then $\mathrm{NO}_{2}^{-}$in culture supernatants was measured to assess NO production levels. Fifty microliters of sample aliquots were mixed with $50 \mu \mathrm{l}$ of Griess reagent (1\% sulfanilamide $/ 0.1 \%$ naphthylethylene diamine dihydrochloride $/ 2 \%$ phosphoric acid) in 96-well plates and incubated at $25^{\circ} \mathrm{C}$ for $10 \mathrm{~min}$. The absorbance at $540 \mathrm{~nm}$ was measured with a microplate reader (Anthos Labtec Instruments). $\mathrm{NaNO}_{2}$ was used as the standard to calculate $\mathrm{NO}_{2}^{-}$ concentrations.

\section{Morphological analysis of astrocytes by immunofluorescence}

Immunofluorescence analysis was performed as described previously (Seo et al., 2008). In brief, astrocytes $\left(1 \times 10^{5}\right.$ cells/well in 24 -well plates) were cultured on sterile coverslips in 24 -well plates, and then fixed with $4 \%$ paraformaldehyde for $30 \mathrm{~min}$ and twice rinsed with PBS. Samples were blocked with $1 \%$ BSA in PBS-Tween 20 for 10 min and incubated in PBS containing 3\% BSA and a mouse anti-GFAP antibody (1:30 dilution) (Biogenex) or $0.12 \mu \mathrm{g} / \mathrm{ml}$ TRITC (tetramethylrhodamine isothiocyanate)-conjugated phalloidin (actin cytoskeleton and focal adhesion staining kit; Millipore Bioscience Research Reagents). After two washes in PBS-Tween 20, wells were incubated with $2.5 \mu \mathrm{g} / \mathrm{ml}$ Hoechst 33342 fluorochrome (Invitrogen) or $0.1 \mu \mathrm{g} / \mathrm{ml}$ DAPI $\left(4^{\prime}, 6^{\prime}\right.$-diamidino2-phenylindole) (Millipore Bioscience Research Reagents), followed by incubation with anti-mouse IgG-fluorescein isothiocyanate (FITC)conjugated secondary antibody (BD Biosciences). The samples were mounted and observed by means of fluorescence microscopy (Olympus BX50) or confocal microscopy (Zeiss LSM 510). Microscopic images were processed by using a MetaMorph Imaging System (Molecular Devices). Astrocyte processes were quantified as previously described, but with a slight modification (Wilhelmsson et al., 2004; Borán and García, 2007). The average process length was based on the longest process for each cell from a minimum of five randomly chosen microscopic fields containing at least 100 cells.

Flow cytometric analysis of apoptosis and cell cycle

Astrocytes $\left(1 \times 10^{5}\right.$ cells/well in 24-well plates $)$ were detached with trypsin-EDTA, and washed twice with cold PBS. The cells were then resuspended in $250 \mu \mathrm{l}$ of binding buffer ( $10 \mathrm{~mm}$ HEPES, $140 \mathrm{~mm} \mathrm{NaCl}$, $2.5 \mathrm{~mm} \mathrm{CaCl}_{2}, \mathrm{pH} 7.4$ ) and incubated with $3 \mu \mathrm{l}$ of FITC-conjugated annexin $\mathrm{V}$ (Invitrogen) according to the manufacturer's specifications. Afterward, cells were gently vortexed and incubated for $15 \mathrm{~min}$ at room temperature in darkness. Propidium iodide (PI) $(20 \mu \mathrm{g} / \mathrm{ml})$ was then added, and flow cytometry was performed within $1 \mathrm{~h}$ using FACSAria (BD Biosciences). For the purpose of analyzing cell cycle distribution, cells were suspended in PBS/5 mM EDTA, and fixed by adding $100 \%$ ethanol dropwise. RNase A $(40 \mu \mathrm{g} / \mathrm{ml})$ was added to the resuspended cells, and then incubation was conducted at room temperature for 30 min. Propidium iodide $(100 \mu \mathrm{g} / \mathrm{ml})$ was added and incubated for $30 \mathrm{~min}$. The percentage of cells in each phase of the cell cycle was determined by means of flow cytometry by using a FACSCalibur (BD Biosciences).

\section{Reverse transcription-PCR}

Total RNA was extracted from either C6 cells or primary astrocyte cultures in six-well plates by using TRIzol reagent (Invitrogen), according to the manufacturer's protocol. Reverse transcription was performed by using Superscript (Invitrogen) and oligo-dT primer. PCR amplification, using specific primer sets, was performed at a $60^{\circ} \mathrm{C}$ annealing temperature for 25 cycles as previously described (Kim et al., 2004). Nucleotide 
Table 1. DNA sequences of the primers used for RT-PCR

\begin{tabular}{|c|c|c|c|}
\hline CDNAs & Primer sequences & GenBank accession no. & RT-PCR product size (bp) \\
\hline Rat /cn2 & $\begin{array}{l}\text { Forward, 5' -GGG GAC AAG TTT GTA CAA AAA AGC } \\
\text { AGG CTC CAC CAT GGG CCT GGG TGT CCT GTG T-3' } \\
\text { Reverse, 5' -GGG GAC CAC TTT GTA CAA GAA AGC TGG } \\
\text { GTT GTT GTC AAT GCA TTG GTC GGT-3' }\end{array}$ & NM_130741 & 658 \\
\hline Mouse/rat Icn2/24p3R & $\begin{array}{l}\text { Forward, 5' -AAT GAC TCT CAC GGG GAT TG-3' } \\
\text { Reverse, 5' -AGT GGT GGG GAT GAC TTC AG-3' }\end{array}$ & NM_021551 (mouse); NM_177421 (rat) & 157 \\
\hline Rat bim & $\begin{array}{l}\text { Forward, 5' -GCC CCT ACC TCC CTA CAG AC-3' } \\
\text { Reverse, 5'-CAG GTT CCT CCT GAG ACT GC-3' }\end{array}$ & AF136927 & 423 \\
\hline Mouse gfap & $\begin{array}{l}\text { Forward, 5'-AGG CAG AAG CTC CAA GAT GA-3' } \\
\text { Reverse, 5' -TGT GAG GTC TGC AAA CTT GG-3' }\end{array}$ & NM_010277 & 342 \\
\hline Mouse vimentin & $\begin{array}{l}\text { Forward, 5'-TGC ACG ATG AAG AGA TCC AG-3' } \\
\text { Reverse, 5' -TCT TCC ATC TCA CGC ATC TG-3' }\end{array}$ & $X 56397$ & 337 \\
\hline Mouse/rat megalin & $\begin{array}{l}\text { Forward, 5' -CCA GAA AAT GTG GAA AAC CAG-3' } \\
\text { Reverse, 5' -ACA AGG TTT GCG GTG TCT TT-3' }\end{array}$ & NM_001081088 (mouse); NM_030827 (rat) & 308 \\
\hline Mouse/rat $\beta$-actin & $\begin{array}{l}\text { Forward, 5' -ATC CTG AAA GAC CTC TAT GC-3' } \\
\text { Reverse, 5' -AAC GCA GCT CAG TAA CAG TC-3' }\end{array}$ & X03672 (mouse); NM_031144 (rat) & 287 \\
\hline
\end{tabular}

sequences of the primers were based on published cDNA sequences (Table 1). The PCR was performed by using a DNA Engine Tetrad Peltier Thermal Cycler (MJ Research). For the analysis of PCR products, $10 \mu \mathrm{l}$ of each PCR was electrophoresed on $1 \%$ agarose gel and detected under UV light. $\beta$-Actin was used as an internal control.

\section{Western blot analysis}

Cells in six-well plates were lysed in triple-detergent lysis buffer $(50 \mathrm{~mm}$ Tris- $\mathrm{HCl}, \mathrm{pH} 8.0,150 \mathrm{~mm} \mathrm{NaCl}, 0.02 \%$ sodium azide, $0.1 \%$ SDS, $1 \%$ NP-40, $0.5 \%$ sodium deoxycholate, $1 \mathrm{~mm}$ phenylmethylsulfonyl fluoride). Protein concentration in cell lysates was determined by using a Bio-Rad protein assay kit (Bio-Rad). An equal amount of protein from each sample was separated by $12 \%$ SDS-PAGE and transferred to Hybond ECL nitrocellulose membranes (GE Healthcare). The membranes were blocked with $5 \%$ skim milk and sequentially incubated with primary antibodies [goat polyclonal anti-mouse LCN2 antibody (R\&D Systems); rabbit polyclonal anti-mouse LCN2/NGAL antibody (Santa Cruz Biotechnology); rat monoclonal anti-BIM antibody (Calbiochem); mouse monoclonal anti-GFAP antibody (Biogenex); monoclonal anti$\alpha$-tubulin clone B-5-1-2 mouse ascites fluid (Sigma-Aldrich)] and HRPconjugated secondary antibodies (anti-goat, anti-rabbit, anti-rat, and anti-mouse IgG; GE Healthcare), followed by ECL detection (GE Healthcare). Two kinds of anti-LCN2 antibody were used in this study: goat polyclonal antibody (R\&D Systems) was used for the detection of LCN2 protein in mouse astrocytes, and rabbit polyclonal antibody (Santa Cruz Biotechnology) was used for the detection of LCN2 protein in C6 rat glioma cells and zebrafish. For the purpose of the detection of secreted LCN2 protein in astrocyte cultures, Western blot analysis of culture media was performed. In brief, astrocyte cultures grown in $100 \mathrm{~mm}$ culture dishes were washed five times with PBS. Cells were then covered with a minimal volume of culture medium, and treated with stimulating agents at $37^{\circ} \mathrm{C}$. Conditioned media were collected and centrifuged successively at $2000 \times g(5 \mathrm{~min})$ and $15,600 \times g(10 \mathrm{~min})$ to remove nonadherent cells and debris. Samples were then precipitated with trichloroacetic acid (TCA) and acetone mixture (10\% TCA and $10 \mathrm{~mm}$ DTT in acetone) at $-20^{\circ} \mathrm{C}$ overnight as previously described (Kim et al., 2007). Precipitated proteins were subjected to the SDS-PAGE and Western blot detection of LCN2.

\section{Rho GTPase activity assay}

Cells were treated with stimuli in a $100 \mathrm{~mm}$ culture dish, washed with cold PBS, and lysed in a lysis buffer [20 mM Tris-HCl, pH 7.6, $100 \mathrm{~mm}$ $\mathrm{NaCl}, 10 \mathrm{mM} \mathrm{MgCl}_{2}, 1 \%$ Nonidet P-40, 10\% glycerol, and protease inhibitor mixture (Roche Molecular Biochemicals)]. Lysates were clarified, protein concentrations were determined, and the GTP-bound Rho in the lysates was measured by the effector pulldown assay using the EZ-Detect Rho activation kit (Pierce). In brief, cell lysates were incubated with the agarose-immobilized glutathione $S$-transferase (GST)-Rhotekin, and the coprecipitates were subjected to anti-Rho Western blot analysis to assess the amount of GTP-bound Rho proteins. The anti-Rho antibody used in this study is known to recognize RhoA, RhoB, and RhoC.

\section{Gateway cloning and stable transfection of lcn 2 cDNA}

Reverse transcription-PCR (RT-PCR) was performed by using total RNAs isolated from C6 rat glioma cells. Rat lcn2 cDNA sequences of either sense or antisense orientation were PCR amplified from the pooled cDNAs, using target sequence-specific primers by Gateway cloning (Invitrogen). The sequences of PCR primers used for Gateway cloning were as follows: sense lcn2 forward, 5' -GGGG ACA AGT TTG TAC AAA AAA GCA GGCT CCA CC ATG GGC CTG GGT GTC CTG TGT-3'; sense lcn2 reverse, $5^{\prime}$-GGGG ACC ACT TTG TAC AAG AAA GCT GGG TTG TT GTC AAT GCA TTG GTC GGT-3'; antisense lcn2 forward, 5' GGGG ACA AGT TTG TAC AAA AAA GCA GGCT CCA CC ATG TCA GTT GTC AAT GCA TTG GTC-3'; antisense lcn2 reverse, 5'-GGGG ACC ACT TTG TAC AAG AAA GCT GGG TTG TT ATG GGC CTG GGT GTC CTG TGT- ${ }^{\prime}$. The forward primers were used to introduce att $\mathrm{B} 1$ sequence (underlined), followed by a Kozak sequence (CCACC) and the gene-specific sequence (bold). Similarly, the reverse primers were used to introduce attB2 sequence (underlined), followed by the gene specific sequence (bold). The PCR products were cloned into the pDONR207 donor vector (Invitrogen), their sequences confirmed (Macrogen), and finally converted into the pDS-GFP-XB destination vector (Invitrogen). C6 cells in six-well plates were transfected with $4 \mu \mathrm{g}$ of green fluorescent protein (GFP)-tagged sense or antisense rat lcn $2 \mathrm{cDNA}$ by using lipofectAMINE reagent (Invitrogen). An empty pEGFP vector was used as a control for the stable expression of $1 \mathrm{cn} 2$. Stable transfectants were selected in the presence of G418 $(800 \mu \mathrm{g} / \mathrm{ml})$ at a period of $2 \mathrm{~d}$ after the transfection. Upregulation or downregulation of lcn 2 mRNA or protein in the stable transfectants was confirmed by either RT-PCR or Western blot analysis, respectively.

\section{Stable transfection of bim short hairpin RNA}

The short hairpin RNA (shRNA) sequences specific for rat bim cDNA (GenBank accession number AF136927) were designed using BLOCK-iT RNAi Designer software (Invitrogen). The nucleotides 320-340 of bim cDNA coding region ( $5^{\prime}$-GGG CGT TTG CAA ACG ATT ACC-3') were targeted. The oligonucleotide with stem, loop, transcription termination sequences, and restriction sites was cloned into EcoRI and XbaI site of pU6shX vector (small hairpin RNA expression vector; VectorCoreA) to generate pU6shX-bim. C6 cells in six-well plates were cotransfected with a 1:10 ratio of pU6shX-bim and pSV2neo containing the neomycinresistance gene (Clontech) by using lipofectAMINE reagent (Invitrogen). An empty pU6shX vector was used as a control. Stable transfectants were selected in the presence of G418 $(400 \mu \mathrm{g} / \mathrm{ml})$ at a period of $2 \mathrm{~d}$ after the transfection. Downregulation of bim mRNA or protein in the stable 
transfectants was confirmed by either RT-PCR or Western blot analysis, respectively.

\section{Virus and infection}

Recombinant adenovirus expressing rat lcn2-GFP (Ad-lcn2-GFP) was generated by Newgex. Briefly, cDNA encoding rat lcn2-GFP was inserted into the pShuttle-cytomegalovirus vector (Clontech). The pShuttlecytomegalovirus with rat lcn2-GFP was linearized with PmeI and cotransformed into BJ5183 E. coli along with the pAdEasy-1 (Clontech) adenoviral vector. Transformed cells were overlaid on kanamycincontaining agarose plates, and individual colonies were checked for the presence of the proper recombinant. After sequence confirmation, recombinant adenoviral stocks were expanded by infection of HEK-293A cells, followed by extraction. Adenovirus was semipurified from hightiter supernatants of infected HEK-293A cells. Supernatants were clarified by means of centrifugation to eliminate cell debris and stored at $-80^{\circ} \mathrm{C}$. C6 cells were infected with adenovirus expressing GFP (Ad-GFP) or rat lcn2-GFP for $2 \mathrm{~d}$, and then cells were observed by means of fluorescence microscopy. Several randomly chosen microscopic fields were examined. Ad-GFP was used as a control.

\section{Purification of recombinant lipocalin 2 protein}

Recombinant mouse LCN2 protein was prepared as previously described (Yang et al., 2002). In brief, recombinant mouse LCN2 protein was expressed as a GST fusion protein in the BL21 strain of E. coli, which does not synthesize siderophore. The protein was purified by using glutathione-Sepharose 4B beads (GE Healthcare), followed by elution with either thrombin or glutathione. For iron and enterochelin loading, a fivefold molar excess of ion-saturated enterochelin (EMC Microcollections) was mixed with the purified recombinant LCN2 protein.

\section{Phagocytosis assay}

Primary astrocytes were seeded at $1 \times 10^{6}$ cells/well in six-well plates. After removal of media, $20 \mu \mathrm{g} / \mathrm{ml}$ fluorescent zymosan particle [zymosan A (Saccharomyces cerevisiae) BioParticles; Alexa Fluor 594 conjugate (Invitrogen)] was added to each well, allowed to settle by gravity, and left for $1-3 \mathrm{~h}$. After unbound particles were thoroughly removed by three washes with ice-cold PBS, the medium was replaced. The samples were either observed by fluorescence microscopy (Olympus BX50) or analyzed by flow cytometry using a FACSAria (BD Biosciences).

\section{Cell migration assays}

Migration was measured by using a 48 -well Boyden chamber (NeuroProbe). DMEM was placed into base wells separated from the top wells by polyvinylpyrrolidone-free polycarbonate filters ( $8 \mu \mathrm{m}$ pore size; $25 \times 80$ $\mathrm{mm}$; NeuroProbe). Cells were harvested by trypsinization, resuspended in DMEM, and added to the upper chamber at a ratio of $1 \times 10^{4}$ cells/ well. Cells were incubated at $37^{\circ} \mathrm{C}$ under $5 \% \mathrm{CO}_{2}$. At the end of the experiment, cells were fixed with methanol for $10 \mathrm{~min}$ and stained with modified Giemsa stain (Sigma-Aldrich) for $1 \mathrm{~h}$. Cells on the upper side of the membrane were then removed by using a cotton swab. The migrated cells were counted under a light microscope (Olympus CK2) (magnifications, $\times 100)$. All migrated cells were counted, and the results were presented as mean \pm SD (total number of migrated cells) of triplicates. For the in vitro wound healing assay, a scratch wound was created by using a $10 \mu \mathrm{l}$ pipette tip on confluent cell monolayers in 24-well culture plates, and placed into DMEM containing $10 \% \mathrm{FBS}, 100 \mathrm{U} / \mathrm{ml}$ penicillin, and $100 \mu \mathrm{g} / \mathrm{ml}$ streptomycin. Cells were incubated at $37^{\circ} \mathrm{C}$ under $5 \%$ $\mathrm{CO}_{2}$ during migration of monolayer into the cleared wound area. The wound area was observed by microscopy (Olympus CK2) (magnifications, $\times 100$ ). Relative cell migration distance was determined by measuring the wound width and subtracting this from the initial value as previously described: cell migration distance $=$ initial wound width at day 0 - wound width at the day of measurement (Bassi et al., 2008). A total of three areas were randomly selected and examined in each well. The results were presented as a fold increase in the migration distance: fold increase $=$ cell migration distance at the day of measurement/cell migration distance at day 1.

\section{Zebrafish analysis}

Fish breeding and maintenance. Embryos were collected from pair mating, raised at $28.5^{\circ} \mathrm{C}$ in egg water, and staged according to days postfertilization (dpf) as previously described (Park et al., 2005; Kucenas et al., 2008). Wild-type $\mathrm{AB}$ and $\mathrm{Tg}$ (GFAP:egfp) fish expressing enhanced green fluorescent protein (EGFP) under the control of GFAP promoter (Bernardos and Raymond, 2006) were used for this study.

RNA injection. For mRNA injection experiments, a rat $1 \mathrm{cn} 2 \mathrm{cDNA}$ containing a full-length open reading frame was subcloned into the pCSDest vector (Villefranc et al., 2007), and mRNA was produced by the Message Machine kit (Ambion). Generation of the lcn2 message was confirmed by gel electrophoresis of transcription reaction (data not shown). One hundred picograms of $1 \mathrm{cn} 2$ mRNA was injected into the yolks of one- to two-cell-stage embryos. Expression of LCN2 protein in the mRNA-injected embryos was confirmed by immunocytochemistry (data not shown).

Immunocytochemistry. Embryos were fixed in AB Fix (4\% paraformaldehyde, $8 \%$ sucrose, $1 \times \mathrm{PBS}$ ) overnight at $4^{\circ} \mathrm{C}$, embedded in $1.5 \%$ agarose $/ 30 \%$ sucrose, and frozen in 2-methyl butane chilled by immersion in liquid nitrogen. We collected $10 \mu \mathrm{m}$ of transverse sections by using a cryostat microtome. For immunocytochemistry purposes, we used the following primary antibodies: mouse antibody to $\mathrm{Zrf}-1$ (1:400 dilution; University of Oregon Monoclonal Antibody Facility, Eugene, OR), rabbit polyclonal anti-LCN2/NGAL antibody (1:100 dilution; Santa Cruz Biotechnology). The relative length, thickness, and number of processes of zebrafish radial glia cells were quantified as follows: the five longest or thickest cellular processes for each section were measured. The total number of processes was also counted for each section. Seven zebrafish sections for each treatment were quantified. The results were normalized to the diameter of the spinal cord [ (vertical diameter + horizontal diameter)/2)] and presented as mean $\pm \operatorname{SEM}(n=7)$.

\section{Statistical analysis}

All data were presented as mean \pm SD from three or more independent experiments, unless stated otherwise. Statistical comparisons between different treatments were done by either a Student's $t$ test or one-way ANOVA with Dunnett's multiple-comparison tests by using the GraphPad Prism program (GraphPad Software). Differences with a value of $p<0.05$ were considered to be statistically significant.

\section{Results}

lcn2 increased the sensitivity of astrocytes to cytotoxic stimuli We have previously shown that inflammatory activation of cultured microglia and astrocytes induces their own apoptosis (J. Lee et al., 2001; Suk et al., 2002). Because of the fact that $\operatorname{lcn} 2$ is involved in the survival and death of a variety of cell types, we investigated how lcn2 participates in the cell death of activated astrocytes by means of a series of experiments: (1) stable overexpression or knockdown of lcn2 expression by transfection with sense or antisense lcn2 cDNA in C6 rat glioma cells; (2) adenovirus-mediated transient expression of lcn 2 in $\mathrm{C} 6$ cells; and (3) treatment of primary astrocyte cultures or C6 cells with recombinant LCN2 protein. First, C6 cells with an increased or decreased expression of $1 \mathrm{cn} 2$ were obtained by stable transfection with sense or antisense lcn 2 cDNA. Changes in the lcn2 mRNA, as well as protein, expression in the stable transfectants (lcn2 sense transfectant, S3; Icn2 antisense transfectant, AS7) were confirmed by RT-PCR and Western blot analysis, respectively (Fig. $1 A$ ). The stable overexpression of $1 \mathrm{cn} 2$ enhanced the sensitivity of C6 glia cells to a $\mathrm{NO}$ donor $\mathrm{SNP}, \mathrm{H}_{2} \mathrm{O}_{2}$, and paraquat (Fig. $1 B-D$; supplemental Table 1, available at www.jneurosci.org as supplemental material), which have been previously shown to induce astrocyte cell death (Suk et al., 2001; Son et al., 2005; Kim et al., 2008). A similar result was obtained with another NO donor, known as SNAP (data not shown). In contrast, a stable knockdown of lcn2 expression by transfection with the antisense lcn2 construct decreased the sensitivity of glia cells to the cytotoxic 

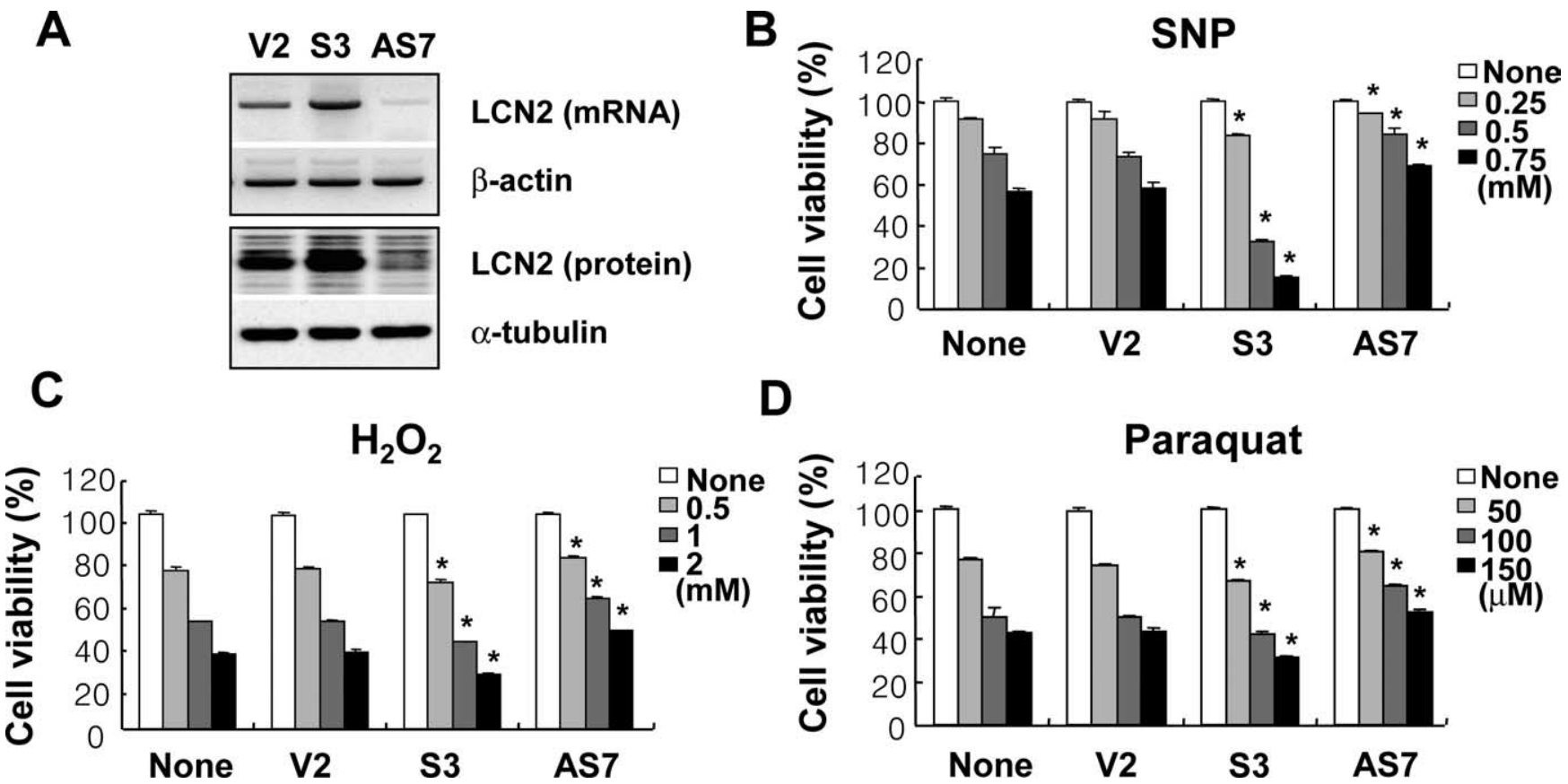

D

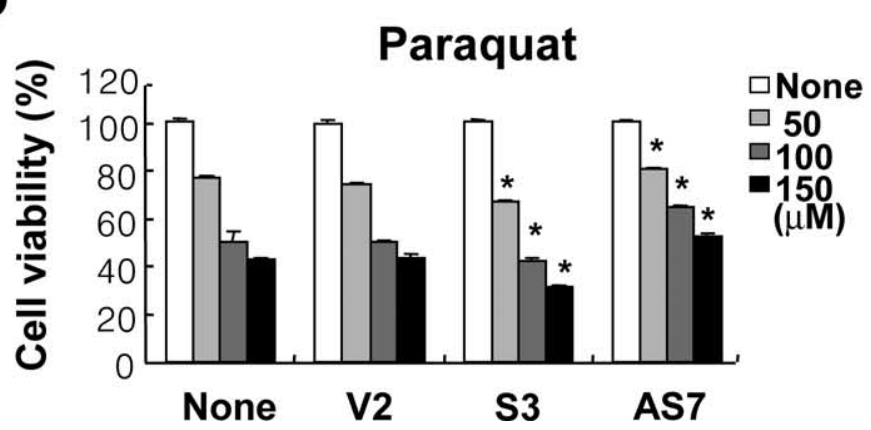

Figure 1. Inverse correlation between the level of Icn2 expression and the sensitivity of astrocytes to cytotoxic agents. (6 glial cells with an increased or decreased lcn2 expression were established by stable transfection of Icn2 sense (S3) or antisense (AS7) CDNA. The increased or decreased Icn2 expression in the stable transfectants compared with cells transfected with an empty vector (V2) was confirmed by RT-PCR (top) and Western blot analysis (bottom) (A). $\beta$-Actin or $\alpha$-tubulin was also detected to confirm the equal loading of the samples. Compared with the empty vector transfectant (V2), the lcn2 sense (S3) or antisense (AS7) stable transfectants showed an increased or decreased sensitivity, respectively, to cytotoxic agents such as $\mathrm{SNP}, \mathrm{H}_{2} \mathrm{O}_{2}$, and paraquat $(\boldsymbol{B}-\boldsymbol{D})$. Cells were treated with the indicated concentrations of cytotoxic agents for $24 \mathrm{~h}$, and cell viability was assessed by MTT assay. The asterisks indicate statistically significant differences from the empty vector transfectant (V2) treated with the same concentrations of cytotoxic agents (V2 vs S3 or V2 vs AS7) $(p<0.05)$. The results are mean \pm SD $(n=3)$. The results in this and all similar experiments were repeated several times, and one representative done in triplicate is shown.

agents (Fig. $1 B-D$; supplemental Table 1, available at www.jneurosci.org as supplemental material). Second, transient overexpression of lcn2 was achieved by using an adenoviral vector harboring lcn $2 \mathrm{cDNA}$ fused to GFP (Fig. 2A,B). The adenoviral expression of $1 \mathrm{cn} 2$ also increased the sensitivity of C6 glia cells to $\mathrm{H}_{2} \mathrm{O}_{2}$, paraquat, SNP, and a combination of LPS and IFN- $\gamma$ (Fig. 2C). Additionally, a recombinant mouse LCN2 protein was prepared and tested for potential cytotoxic effects (Fig. $3 A$ ). The LCN2 protein sensitized primary astrocyte cultures to cell death, whereas LCN2 protein alone did not affect astrocyte viability (Fig. $3 B, C$ ). The cell deathenhancing effects of LCN2 protein were also assessed by PI and annexin $\mathrm{V}$ staining followed by flow cytometric analysis to determine the nature of cell death (Table 2; supplemental Fig. 1, available at www. jneurosci.org as supplemental material). Treatment with LCN2 protein increased the sensitivity of astrocytes to apoptosis $\left(\mathrm{PI}^{-} /\right.$annexin $\mathrm{V}^{+}$or $\mathrm{PI}^{+} /$annexin $\left.\mathrm{V}^{+}\right)$as well as necrosis $\left(\mathrm{PI}^{+} /\right.$annexin $\left.\mathrm{V}^{-}\right)$. LCN2 sensitized astrocytes to NO-induced apoptotic cell death as well as $\mathrm{H}_{2} \mathrm{O}_{2}$ - or paraquat-induced necrotic cell death. The cell death-enhancing effects of LCN2 protein were dose dependent, and statistically significant effects were observed from $10 \mathrm{ng} / \mathrm{ml}$ LCN2 (Fig. 3D). LCN2, however, did not significantly influence the cell cycle distribution of either C6 glia cells or

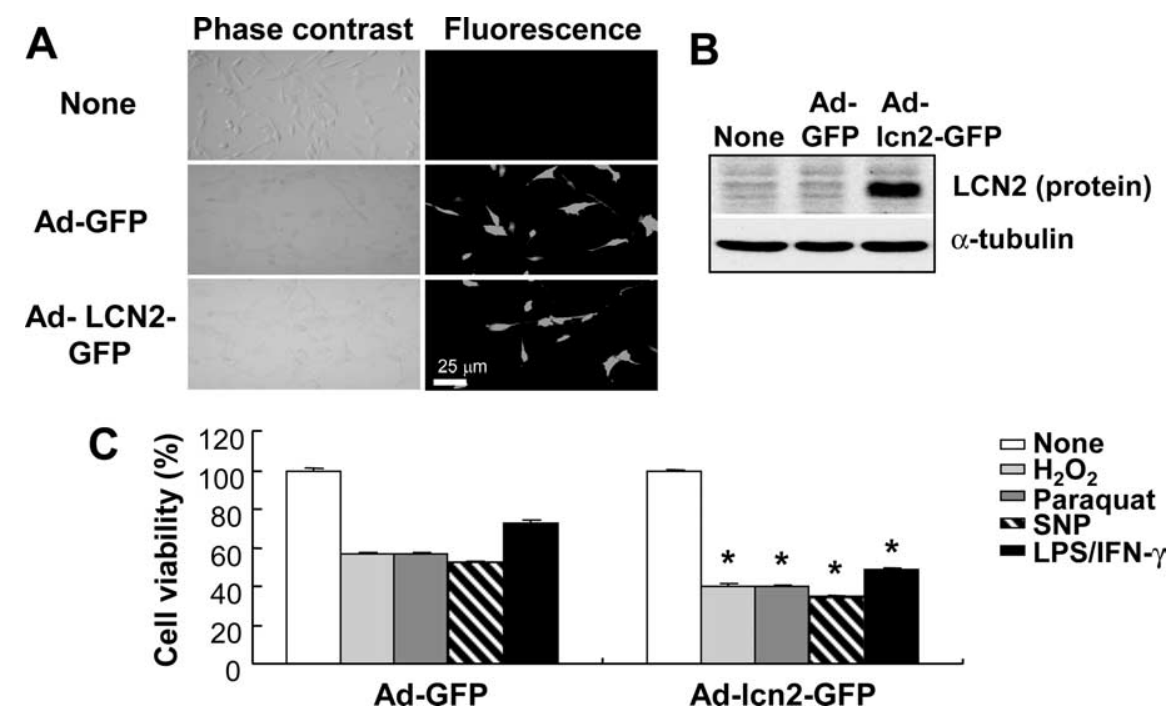

Figure 2. Augmented cell death in the astrocytes that were infected with adenoviral vector expressing lcn2. (6 glial cells were infected with adenoviral vectors expressing GFP (Ad-GFP) or Icn2 fused with GFP (Ad-Icn2-GFP) for $2 d$, and then observed under fluorescence microscope $(\boldsymbol{A})$. Magnification, $\times 200$. Overexpression of Icn2-GFP fusion protein was confirmed by Western blot analysis using rabbit polyclonal anti-LCN2/NGAL antibody in the virus-infected cells (B). Virus-infected cells were treated with cytotoxic agents such as $\mathrm{H}_{2} \mathrm{O}_{2}(1 \mathrm{mM})$, paraquat $(100 \mu \mathrm{M}), \operatorname{SNP}(0.5 \mathrm{mM})$, or a combination of LPS $(100 \mathrm{ng} / \mathrm{ml})$ and IFN- $\gamma(50 \mathrm{U} / \mathrm{ml})$ for $24 \mathrm{~h}$, and then cell viability was assessed by MTT assay (C). The asterisks indicate statistically significant differences from the GFP-expressed cells (Ad-GFP) exposed to the same stimulus ( $p<0.05$; Ad-GFP vs Ad-In2-GFP). Values represent mean \pm SD. 


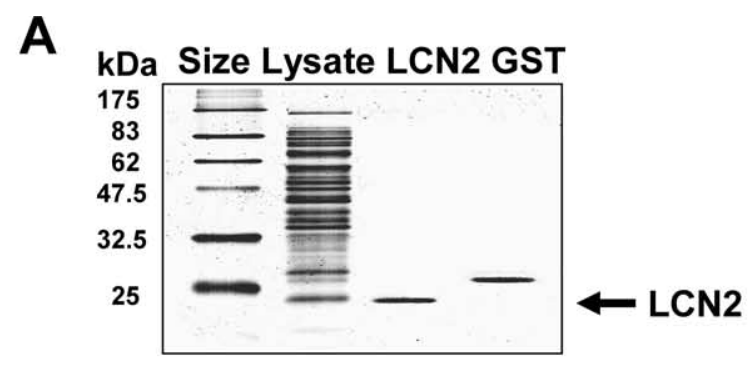

B

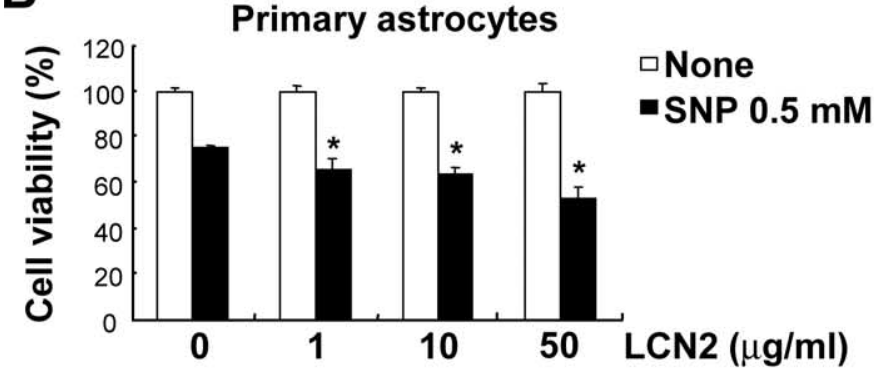

C

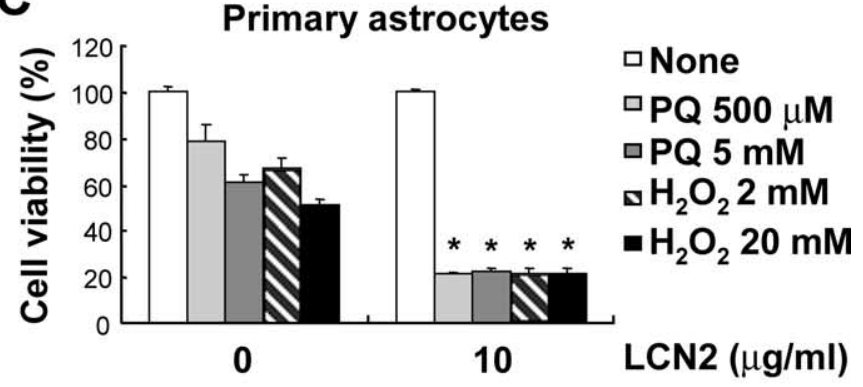

D

Primary astrocytes

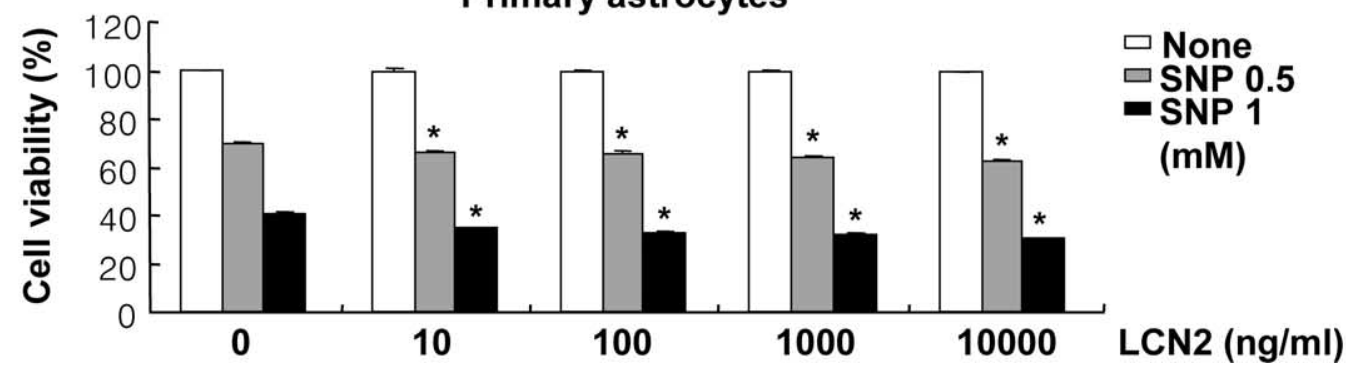

Figure 3. Recombinant LCN2 protein sensitized astrocytes to cell death. GST-fused LCN2 protein was expressed in BL21 cells, which was then cleaved by thrombin to release the pure LCN2 protein (A). The GST protein eluted was run on the same gel for comparison. Treatment with recombinant Icn2 protein for $24 \mathrm{~h}$ enhanced the sensitivity of astrocytes to $\mathrm{N} 0$ toxicity and oxidative stress ( $\boldsymbol{B}$, C). Primary astrocyte cultures were exposed to the indicated concentration of recombinant LCN2 proteins with SNP, paraquat ( $(\mathrm{PQ})$, or $\mathrm{H}_{2} \mathrm{O}_{2}$ for $24 \mathrm{~h}$, and then cell viability was evaluated by MTT assay $(\boldsymbol{B}, \boldsymbol{C})$. The LCN2-induced sensitization of astrocytes to $\mathrm{NO}$ toxicity was dose dependent, as measured by MTT assay after $24 \mathrm{~h}(\boldsymbol{D})$. The results are mean $\pm S D(n=3)$. The asterisks indicate statistically significant differences from the control treated with the same cytotoxic agent in the absence of $\operatorname{LCN} 2(p<0.05)$.

Table 2. Flow cytometric analysis of $\mathrm{LCN} 2$-induced cell death sensitization in primary astrocytes

\begin{tabular}{lcl}
\hline Treatment & $\begin{array}{l}\text { Annexin } \mathrm{V}^{+} / \mathrm{PI}^{+}(\%) \\
\text { (apoptosis) }\end{array}$ & $\begin{array}{l}\text { Annexin } \mathrm{V}^{-} / \mathrm{PI}^{+}(\%) \\
\text { (necrosis) }\end{array}$ \\
\hline None & 2 & 6 \\
$\mathrm{LCN2}$ & 2 & 7.1 \\
$\mathrm{SNP}$ & 19.5 & 4.8 \\
$\mathrm{SNP}+\mathrm{LCN2}$ & 37.6 & 5.5 \\
$\mathrm{H}_{2} \mathrm{O}_{2}$ & 5.7 & 12.5 \\
$\mathrm{H}_{2} \mathrm{O}_{2}+\mathrm{LCN} 2$ & 7.3 & 22.8 \\
$\mathrm{PQ}$ & 3.5 & 28.3 \\
$\mathrm{PQ}+\mathrm{LCN} 2$ & 10.2 & 49.4 \\
\hline
\end{tabular}

After primary astrocytes were treated with SNP $(0.5 \mathrm{~mm}), \mathrm{H}_{2} \mathrm{O}_{2}(1 \mathrm{mM})$, or paraquat $(\mathrm{PQ})(100 \mu \mathrm{m})$ with or without LCN2 proteins $(10 \mu \mathrm{g} / \mathrm{ml})$ for $24 \mathrm{~h}$, the nature of cell death was determined by PI and annexin V staining followed by flow cytometry. Percentage of necrotic or apoptotic cell death was based on flow cytometric analysis.

LCN2 protein concentrations in the blood of normal mice are $\sim 100 \mathrm{ng} / \mathrm{ml}$ (or $4 \mathrm{nM}$ ) (Flo et al., 2004; Mori et al., 2005). LCN2 is one of the most highly induced molecules in inflammatory disorders, whose concentrations reach $30 \mu \mathrm{g} / \mathrm{ml}$ in the blood and 40 $\mu \mathrm{g} / \mathrm{ml}$ in the urine (Mori et al., 2005; Schmidt-Ott et al., 2006). Locally, even higher levels may be achieved in pathologic conditions. At $50 \mu \mathrm{g} / \mathrm{ml}, \mathrm{LCN} 2$ induced kidney epithelia differentiation (Yang et al., 2002), epithelial transition of cancer cells (Hanai
Table 3. Cell cycle analysis of $\mathrm{C} 6$ cells and primary astrocytes treated with recombinant LCN2 protein

\begin{tabular}{lllllr}
\hline & \multicolumn{2}{l}{ C6 cells } & & \multicolumn{2}{c}{ Primary astrocytes } \\
\cline { 2 - 3 } Cell phase & None & LCN2 & & None & LCN2 \\
\hline $\mathrm{G}_{0} / \mathrm{G}_{1}(\%)$ & 54.5 & 59.01 & & 72.78 & 73.97 \\
$\mathrm{~S}(\%)$ & 16.95 & 14.45 & & 2.93 & 3.48 \\
$\mathrm{G}_{2} / \mathrm{M}(\%)$ & 13.21 & 18.4 & & 13.5 & 13.55 \\
\hline
\end{tabular}

Cells were treated with LCN2 protein $(10 \mu \mathrm{g} / \mathrm{ml})$ for $24 \mathrm{~h}$, and DNA content and percentage of cells in each phase of cell cycle were determined by flow cytometric analysis. LCN2 did not significantly influence cell cycle distribution of either C6 glial cells or primary astrocytes.

et al., 2005), and apoptosis of pro-B-cells (Devireddy et al., 2005) in an iron-dependent manner (Mori and Nakao, 2007). Purified GST protein (Fig. 3A) was used as a control for the recombinant LCN2 protein. GST did not exert cytotoxicity or astroglial stimulation (data not shown). Although the effects of $1 \mathrm{cn} 2$ were modest in some experiments, a similar result was obtained in the repeated experiments and showed a statistically significant difference.

Role of iron and Bim in the cell death-sensitizing effects of LCN2

Because it has been previously shown that a proapoptotic effect of $\operatorname{lcn} 2$ is associated with iron metabolism (Devireddy et al., 2005), 
A
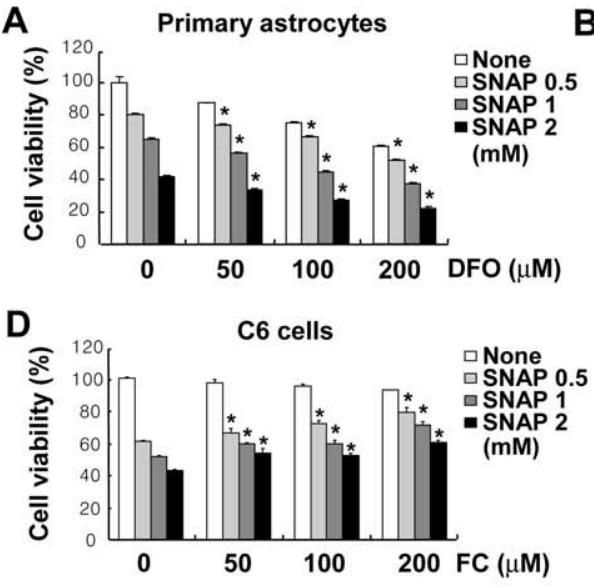

B

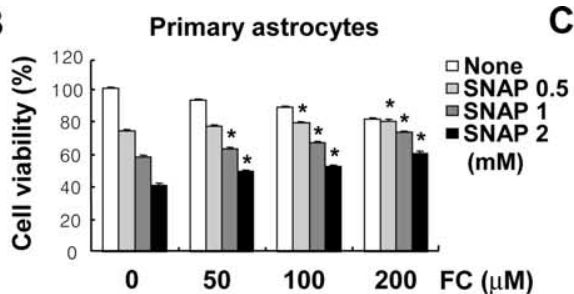

C

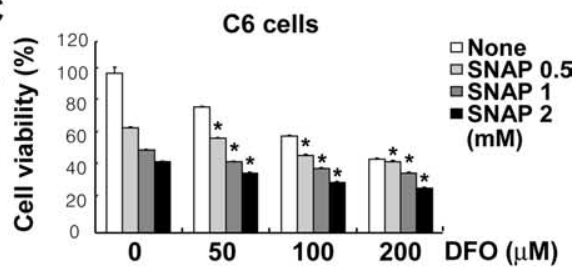

E
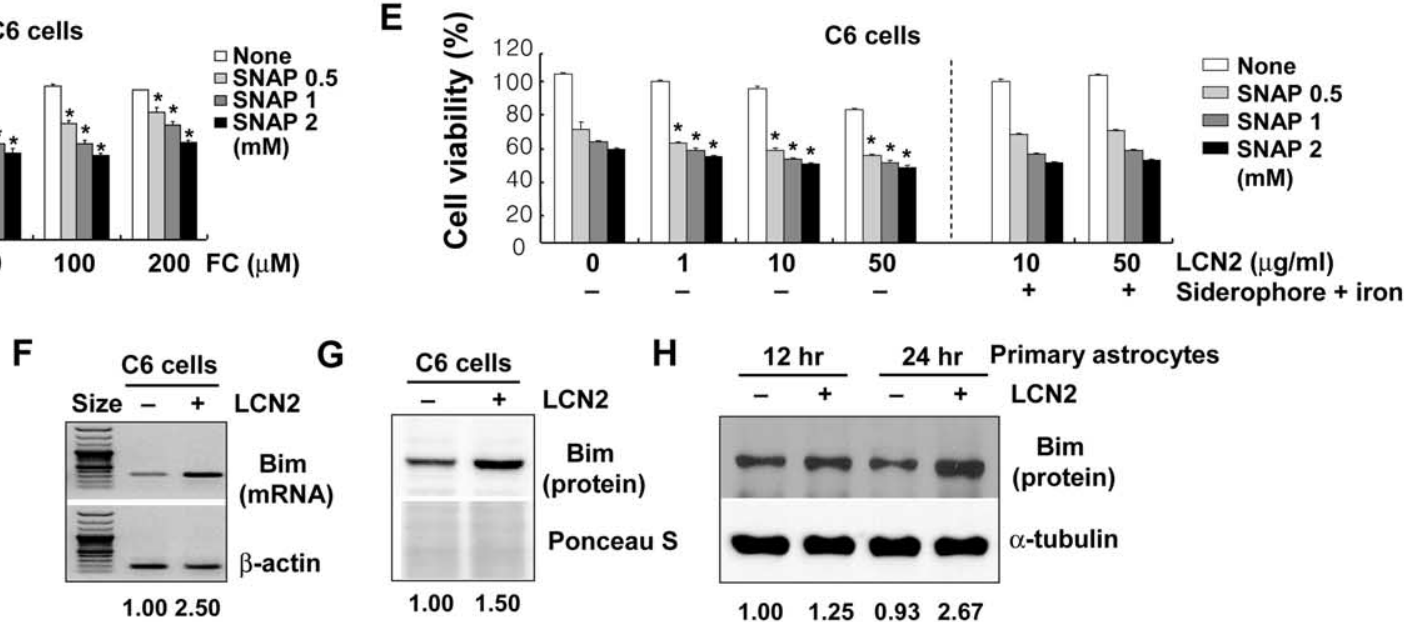

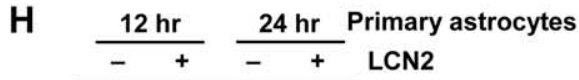
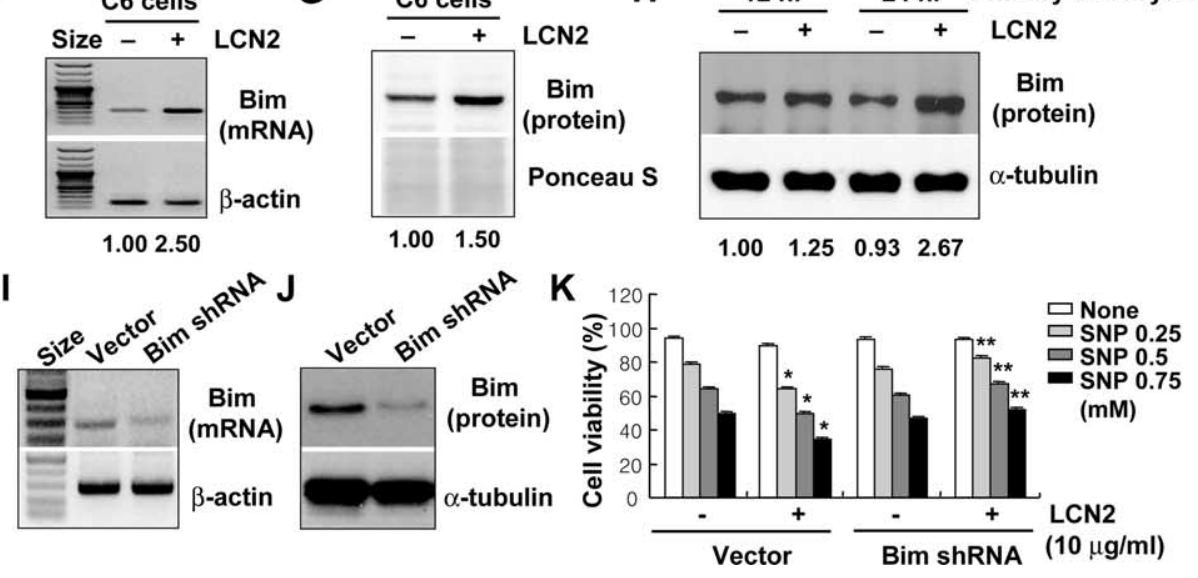

Figure 4. Role of iron and Bim in the LCN2 effects. Primary astrocytes or 6 glial cells were treated with DFO $(A, C)$ or FC $(B, D)$ in the presence of indicated concentrations of the NO donor SNAP for $24 \mathrm{~h}$, and then cell viability was assessed by MTT assay. The iron chelation (DF0) and donation (FC) increased and decreased N0-induced cell death, respectively ( $\boldsymbol{A}-\boldsymbol{D})$. The LCN2-induced cell death sensitization was abolished by the concurrent addition of siderophore-iron complex $(\boldsymbol{E})$. $^{*} p<0.05$ compared with the same concentration of SNAP treatment alone. The expression of proapoptotic BCl-2 family protein BIM was significantly increased by the treatment with recombinant LCN2 protein $(10 \mu \mathrm{g} / \mathrm{ml})$ for 12 or $24 \mathrm{~h}$. This was assessed by RT-PCR $(\boldsymbol{F})$ and Western blot analysis $(\boldsymbol{G}, \boldsymbol{H})$ in $(6$ glia cells $(\boldsymbol{F}, \boldsymbol{G})$ and primary astrocyte cultures $(\boldsymbol{H})$. The results were subjected to densitometric analysis, and normalized relative intensity of the bands is shown below $(\boldsymbol{F}-\boldsymbol{H})$. Stable knockdown of Bim expression by transfection of (6 glia cells with Bim-specific shRNA construct decreased the apoptotic sensitivity compared with the empty vector transfectant. Knockdown of Bim expression was confirmed by RT-PCR $(I)$ and Western blot analysis $(\boldsymbol{J})$ of the transfectants. Bim shRNA-transfected $(6 \mathrm{glia}$ cells were treated with LCN2 protein (10 $\mu \mathrm{g} / \mathrm{ml})$ in the presence of $\operatorname{SNP}(0.25,0.5$, or $0.75 \mathrm{~mm})$ for $24 \mathrm{~h}$, and then cell viability was assessed by MTT assay $(\boldsymbol{K}) . \beta$-Actin $/ \alpha$-tubulin detection or Ponceau $S$ staining was done to confirm the equal loading of the samples. Error bars indicate SD. ${ }^{*} p<0.05$ compared with the same concentration of SNP treatment alone in empty vector transfectants. ${ }^{*} p<0.05$ compared with the same concentration of SNP treatment along with LCN2 in empty vector transfectants.

the effect of either iron chelator deferoxamine (DFO) or iron donor ferric citrate (FC) on astrocyte viability was investigated. It has been previously reported that $1 \mathrm{cn} 2$ containing the iron complex of the bacterial siderophore donates iron to cells via the lcn2 receptor (lcn2R/24p3R) (Devireddy et al., 2005). Internalization of $\ln 2$ and its receptor leads to the uptake of iron from the siderophore-iron complex. The donation of iron to the cell leads to a decrease in transferrin receptor (TfR1) expression and an increase in ferritin levels. In addition, the donation of iron to the cell prevents apoptosis by decreasing the expression of the proapoptotic protein BIM. In contrast, lcn2 without iron complex binds to $\mathrm{ln} 2 \mathrm{R} / 24 \mathrm{p} 3 \mathrm{R}$ and is internalized into the cell. A putative intracellular mammalian siderophore iron complex binds to lcn2, which is subsequently released from the cell by exocytosis. Depletion of iron from cells results in the upregulation of the proapoptotic molecule Bim, which leads to apoptosis (Devireddy et al., 2005). Based on these previous observations and speculations, the role of iron and BIM protein in regard to the cell deathsensitizing effects of $\operatorname{lcn} 2$ was investigated in astrocytes (Fig. 4).
An iron chelator (DFO) alone proved to be modestly toxic to primary astrocytes and C6 glia cells, and increased NO donor (SNAP)-induced astrocyte cell death with an additive effect (Fig. $4 A, C$ ). Because SNP may release iron along with NO (Kim et al., 2006), SNAP was used as a NO donor for this experiment to exclude the effects of minute amounts of iron released by SNP. In contrast, an iron donor (FC) partially prevented the NO donorinduced cell death (Fig. 4B,D). Moreover, lcn2-induced cell death sensitization was abolished by the concurrent addition of the siderophore-iron complex (Fig. $4 E$ ). These results indicate that the cell death-sensitizing activity of lcn2 in astrocytes is related to the iron transport and metabolism: apo-lcn2 may promote cell death by depleting intracellular iron, whereas holo-lcn2 containing the siderophore-iron complex may not. Bcl-2 family proteins have been previously implicated in the effects of $\ln 2$ on cell death and survival (Yousefi and Simon, 2002; Tong et al., 2003; Devireddy et al., 2005). In particular, the upregulation of proapoptotic Bim expression was essential for the apoptosisinducing effects of $1 \mathrm{cn} 2$ (Devireddy et al., 2005). Thus, we deter- 
A

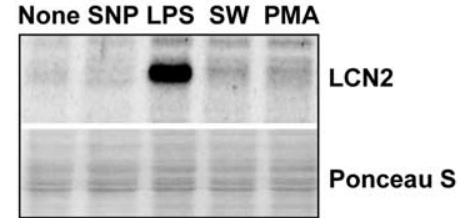

$\begin{array}{lllll}1.00 & 1.68 & 11.5 & 3.82 & 3.99\end{array}$

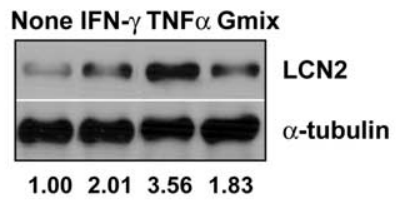

D

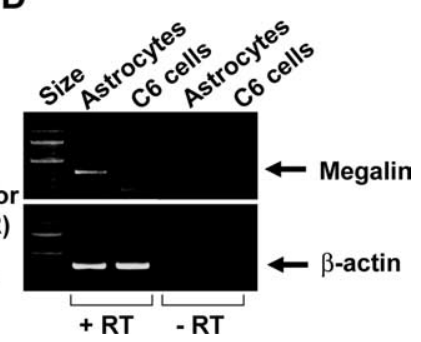

Figure 5. Expression of $\mathrm{Icn} 2$ and $\mathrm{Icn} 2$ receptor $(24 \mathrm{p} 3 \mathrm{R})$ in $\mathrm{C} 6 \mathrm{glia}$ cells and primary astrocytes. The expression of $\mathrm{Icn} 2$ was strongly increased by LPS $(100 \mathrm{ng} / \mathrm{ml})$ or TNF- $\alpha(100 \mathrm{ng} / \mathrm{ml})$ in primary astrocytes after $24 \mathrm{~h}$ treatment as determined by Western blot analysis. Serum withdrawal for $8 \mathrm{~h}$ (SW), PMA (100 $\mu \mathrm{g} / \mathrm{ml})$, IFN- $\gamma(50 \mathrm{U} / \mathrm{ml})$, ganglioside mixture (Gmix) $(50 \mu \mathrm{g} / \mathrm{ml})$, but not SNP $(0.5 \mathrm{~mm})$, treatment for $24 \mathrm{~h}$ slightly increased the protein level $(\boldsymbol{A})$. Secreted LCN2 protein was also detected by Western blot analysis of culture media after similar treatment with LPS $(100 \mathrm{ng} / \mathrm{ml})$ for $24 \mathrm{~h}(\boldsymbol{B})$. Ponceau $S$ staining or $\alpha$-tubulin detection was conducted to confirm the equal loading of the samples. Normalized intensity of the bands is shown below $(\boldsymbol{A}, \boldsymbol{B})$. RT-PCR analysis revealed that $C 6 \mathrm{glial}$ cells and primary astrocyte cultures expressed $\mathrm{lcn} 2$ receptor (24p3R), which has been shown to mediate the apoptotic effect of Icn2 (C). Megalin expression was detected in primary astrocytes, but not 66 cells $(\boldsymbol{D})$. The Icn2 receptor (24p3R) or megalin expression was not detected in the reaction without reverse transcriptase ( $-\mathrm{RT})$. $\beta$-Actin was used as an internal control.

mined the levels of Bim mRNA and protein in the LCN2-treated C6 glia cells and primary astrocytes. Both mRNA and protein levels of Bim were markedly increased by LCN2 protein treatment in C6 glia cells (Fig. 4F, G), as well as in primary astrocyte cultures (Fig. $4 H$ ), supporting the role of Bim in the cytotoxic action of $1 \mathrm{cn} 2$ in astrocytes. Although the effects of $1 \mathrm{cn} 2$ were modest, a similar result was obtained in the repeated experiments. To confirm the role of Bim in the lcn2 action, Bim expression was knocked down using shRNA in C6 cells. Knockdown of Bim expression in the stable transfectants was confirmed by RTPCR (Fig. 4I) or Western blot analysis (Fig. 4J). Stable knockdown of Bim expression by the transfection with the Bim-specific shRNA construct abolished the cell death sensitization effects of lcn2 (Fig. $4 \mathrm{~K}$ ), indicating the important role of Bim in the lcn2 effects. In our previous report, proapoptotic effect of lcn2 on microglia was independent of Bim (Lee et al., 2007). In contrast to astrocytes, Bim expression was not induced by lcn2 in microglia. Although we have not done Bim knockdown experiment in microglia, there appears to be cell type-specific differences in the role of Bim in mediating the lcn2 effects.

\section{Expression and regulation of $1 \mathrm{cn} 2, \mathrm{ln} 2$ receptor $(\mathrm{lcn} 2 \mathrm{R} / 24 \mathrm{p} 3 \mathrm{R})$ in astrocytes}

Previously, lcn2 has been proposed as an acute-phase protein (Liu and Nilsen-Hamilton, 1995), and the expression of lcn2 was modulated by inflammatory stimuli in macrophages (Meheus et al., 1993; Liu and Nilsen-Hamilton, 1995; Cowland et al., 2003). Thus, we sought to determine how the expression of $1 \mathrm{cn} 2$ is regulated by inflammatory or other stimuli in astrocytes. The expression of lcn 2 was strongly enhanced by LPS and TNF- $\alpha$ (Fig. $5 A$ ). Serum withdrawal, PMA, IFN- $\gamma$, and ganglioside mixtures induced a modest increase in lcn2 expression. The secretion of LCN2 was also enhanced by LPS, as determined by Western blot analysis of astrocyte culture media (Fig. 5B). The results indicate that astrocyte expression and secretion of $\operatorname{lcn} 2$ may be increased under inflammatory conditions in the CNS as in regard to macrophages in the periphery. The expression of the $\operatorname{lcn} 2$ receptor $(\operatorname{lcn} 2 \mathrm{R} / 24 \mathrm{p} 3 \mathrm{R})$ that has been shown to mediate lcn2induced cell death (Devireddy et al., 2005) was detected in primary astrocytes and C6 glia cells (Fig. 5C). Expression of another putative lcn2 receptor, megalin, was also detected in primary astrocytes cultures, but not C6 cells (Fig. 5D), suggesting that the common effects of $1 \mathrm{cn} 2$ observed in both primary astrocytes and C6 cells might have been mediated by $24 \mathrm{p} 3 \mathrm{R}$.

\section{LCN2-induced morphological change of astrocytes}

In addition to the cell death-sensitizing effect, the LCN2 protein induced a morphological change of astrocytes in the absence of inflammatory stress or stimuli. When astrocytes were exposed to LCN2 protein, the number and length of cellular processes increased without affecting cell viability (Fig. $6 B-D$ ). This was demonstrated by GFAP staining (Fig. 6A) and phalloidin staining of actin cytoskeleton (data not shown). Because cAMP and cGMP are known to induce similar morphological changes (Borán and García, 2007; Hu et al., 2008), forskolin and dbcGMP were both used for comparison purposes. The LCN2-induced morphological change was dose- and time-dependent (supplemental Fig. 2, available at www.jneurosci.org as supplemental material). A significant change in cell morphology occurred after exposure to LCN2 at concentration of $100 \mathrm{ng} / \mathrm{ml}$ and period of $6 \mathrm{~h}$. A similar pattern of structural changes in astrocytes also occurred after stimulation with LPS/IFN- $\gamma$ or ganglioside mixtures (supplemental Fig. 3, available at www.jneurosci.org as supplemental material), which have been shown to augment lcn2 expression in astrocytes (Fig. 5) and to induce glial activation (Jou et al., 2006; Yoon et al., 2008). The LCN2-induced change in the cellular processes was accompanied by upregulation of GFAP mRNA and protein expression (Fig. 6E,F), which was also LCN2 dose- and time-dependent (supplemental Fig. 4, available at www. jneurosci.org as supplemental material). This type of morphological change in astrocytes is similar to what occurs in reactive astrocytosis in vivo (Boukhelifa et al., 2003; Lin and Cai, 2004; Wilhelmsson et al., 2006). Hypertrophy of cellular processes and increased GFAP expression are two hallmarks of reactive astrocytes after all forms of neural injury in vivo (Wilhelmsson et al., 2004), suggesting the possibility that LCN2 may mediate reactive astrocytosis in vivo. Vimentin expression was, however, not significantly affected by LCN2. We next examined whether the LCN2-induced change in astrocyte morphology is related to the cell death-sensitive phenotype. Forskolin and dbcGMP, which both induced a change in the astrocyte morphology similar to that induced by LCN2, also conferred the cell death-prone phenotype (Fig. 7C). Whereas dbcGMP enhanced lcn2 expression, forskolin failed to do so (Fig. 7A). Both forskolin and dbcGMP, however, did increase GFAP expression, albeit to different extents (Fig. 7B). Although the effect of LCN2 or dbcGMP on GFAP expression was modest, it was reproducibly observed in multiple 
A

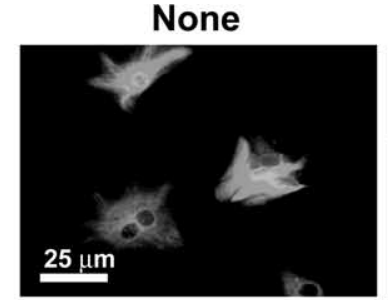

B

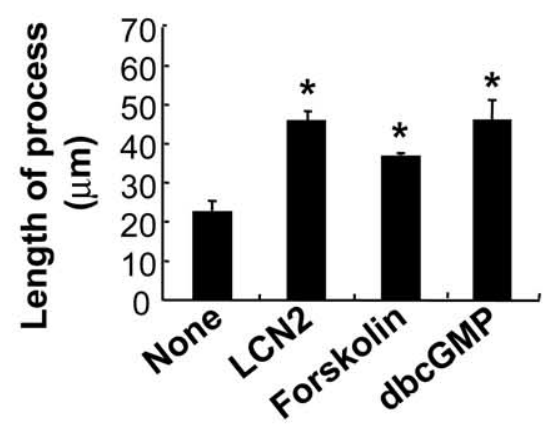

E
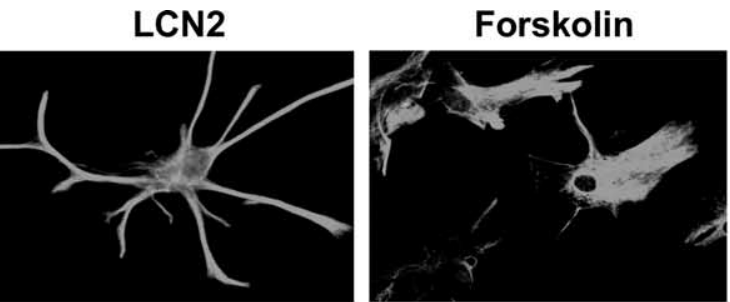

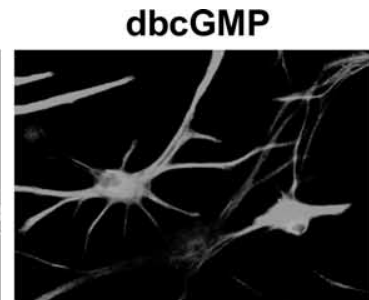

C

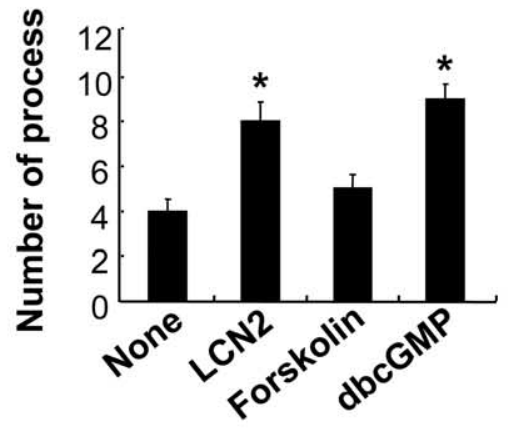

D

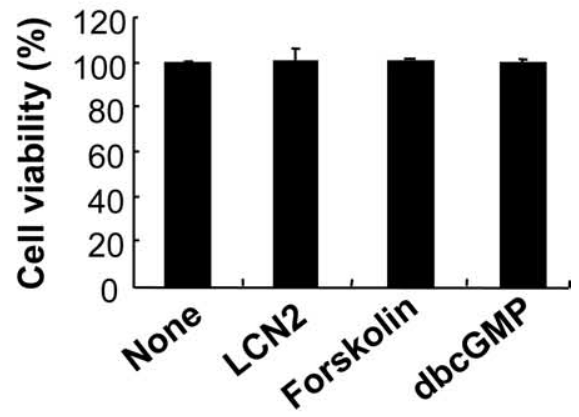

F

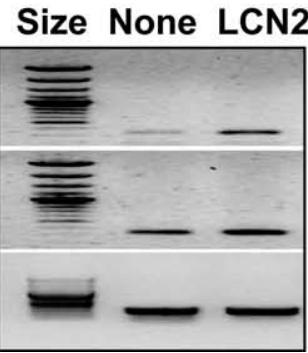

GFAP (mRNA)

Vimentin (mRNA)

\section{None LCN2}

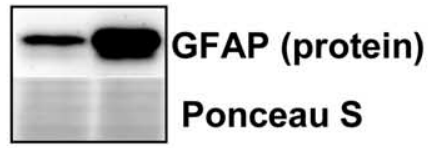

$\beta$-actin

Figure 6. The effect of recombinant LCN2 protein on the morphology and GFAP expression of astrocytes. Addition of recombinant LCN2 protein (10 $\mu \mathrm{g} / \mathrm{ml})$ induced morphological changes in primary astrocyte cultures after $24 \mathrm{~h}(\boldsymbol{A})$, reminiscent of those in reactive astrocytosis in vivo. Treatment with forskolin (100 $\mathrm{nM})$ or dbcGMP (1 mM) for $24 \mathrm{~h}$ also induced a similar morphological change. Cells were double-stained for GFAP (green) and Hoechst 33342 (nuclei; blue) (magnification, $\times 400$ ) (A). Results are one representative of more than three independent experiments. The length $(\boldsymbol{B})$ or number $(\boldsymbol{C})$ of astrocyte processes was measured by examining several randomly chosen fields under fluorescence microscope $(\boldsymbol{B}, \boldsymbol{C})$. No significant cytotoxicity of the stimuli used was confirmed by MTT assay (D). Error bars indicate SD. After primary astrocytes were treated with recombinant LCN2 protein $(10 \mu \mathrm{g} / \mathrm{ml})$ for $24 \mathrm{~h}$, GFAP or vimentin mRNA levels were determined by RT-PCR $(\boldsymbol{E})$, or GFAP protein levels were assessed by Western blot analysis $(\boldsymbol{F})$. Ponceau $S$ staining or $\beta$-actin detection was done to confirm the equal loading of the samples. ${ }^{*} p<0.05$ compared with untreated control.

experiments (data not shown). Our results indicate that dbcGMP and forskolin may induce morphological changes of astrocytes in an lcn2-dependent and -independent manner, respectively. Both forskolin and dbcGMP induced process extension and cell death sensitization. The major difference was that only dbcGMP, but not forskolin, induced $1 \mathrm{cn} 2$ expression. Thus, cGMP may exert its effect through $1 \mathrm{cn} 2$. In contrast, cAMP mediates its effect independently of $\operatorname{lcn} 2$. These results also suggest that morphological changes of astrocytes and their cell death-prone phenotypes are closely related, and that $1 \mathrm{cn} 2$ carries out a dual function in the regulation of astrocyte cell death and morphology. In our previous report, LCN2 also modified microglial morphology (Lee et al., 2007). The cAMP and calcium appear to be involved in the deramification of microglia. In astrocytes, however, cAMP and cGMP led to process extension. Although we have not investigated the lcn 2 dependency for all of these downstream events, the same pathway (e.g., cAMP) seems to work differently in the two cell types with different outcomes. In addition, although microglia and astrocytes share some of the characteristics such as secretion of inflammatory mediators, they show distinct morphological phenotypes when activated. Whereas microglia become deramified on activation, astrocytes show extended processes when they are activated. It appears that LCN2 protein is involved in both events, deramification of microglia and process extension of astrocytes. LCN2 secreted by activated microglia or astrocytes may mediate these distinct morphological changes and yet similar functional phenotypes.

\section{Role of NO in the LCN2 effects}

Recently, NO has been shown to augment GFAP expression in astrocytes (Brahmachari et al., 2006). Because LCN2 also induced GFAP expression in astrocytes in our study (Fig. 6), we next attempted to determine whether NO is involved in the LCN2 actions in astrocytes. First, NO-induced GFAP expression was confirmed at mRNA and protein levels by using a NO donor SNP (Fig. 8A,B). The expression of vimentin used for comparison purposes was not affected. Second, the effect of LCN2 on astrocyte NO production was examined. LCN2 induced a significant increase of $\mathrm{NO}$ production in astrocytes (Fig. $8 \mathrm{C}$ ). The level of LCN2-induced NO production was comparable with that of LPS, and was not abolished by polymyxin B treatment, ruling out the possibility of LPS contamination in the recombinant LCN2 preparation process (Fig. $8 D, E$ ). Recombinant GST protein, which was prepared in the same manner as LCN2, was also used as a 
A

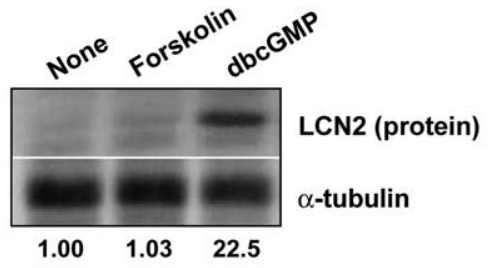

B

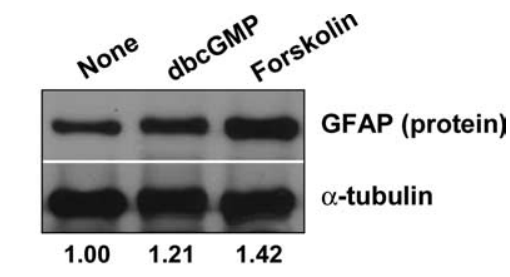

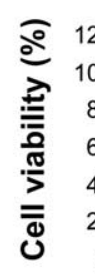

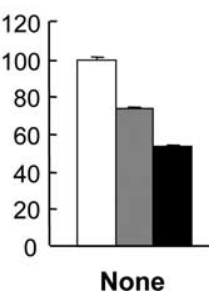

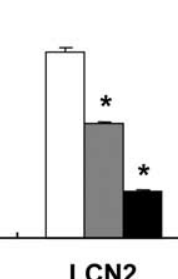
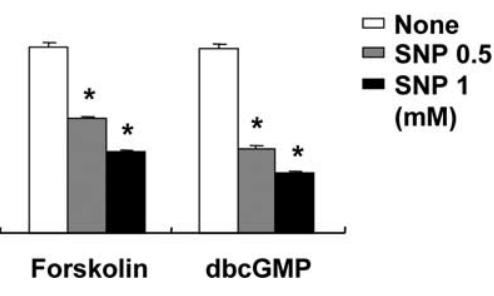

Figure 7. Role of CAMP and CGMP in the expression of LCN2/GFAP and cell death of astrocytes. After primary astrocytes were treated with forskolin (100 nM) or dbcGMP (1 mM) for $24 \mathrm{~h}$, LCN2 or GFAP protein was detected by Western blot analysis $(\boldsymbol{A}, \boldsymbol{B})$. Normalized intensity of the bands is shown below $(\boldsymbol{A}, \boldsymbol{B})$. Primary astrocytes were exposed to LCN2 protein $(10 \mu \mathrm{g} / \mathrm{ml})$ or other stimuli (forskolin, $100 \mathrm{~nm}$; dbcGMP, $1 \mathrm{~mm}$ ) in the presence of SNP ( 0.5 or $1 \mathrm{~mm}$ ) for $24 \mathrm{~h}$, and then cell viability was assessed by MTT assay (C). Error bars indicate SD. ${ }^{*} p<0.05$ compared with the same concentration of SNP treatment alone.

tion is a cellular phenotype that is closely associated with cell morphology, we next examined the effect of LCN2 on the astrocyte migration. As expected, LCN2 enhanced the capability of astrocytes to migrate on the basis of both in vitro wound healing assay (Fig. 10A,C) and Boyden chamber assay (Fig. $10 B, D$ ). LCN2 accelerated wound closures (Fig. 10A,C) as well as migration across the membrane (Fig. $10 B, D$ ) (supplemental Fig. 7, available at www.jneurosci.org as supplemental material). As shown in Figure $10 \mathrm{~A}$, the scratch wound was almost completely closed at day 4 in LCN2- or dbcGMP-treated astrocytes (for the microscopic data on other experimental days, see supplemental Fig. 7, available at www.jneurosci.org as supplemental material). The phagocytic activity of astrocytes was, however, not affected by LCN2 (supplemental Fig. 8, available at www. jneurosci.org as supplemental material). control to further exclude the possibility of LPS contamination (Fig. $8 D$ ). LPS/IFN- $\gamma$-induced NO production was completely inhibited by polymyxin B treatment (Fig. $8 E$ ). Third, the LCN2induced GFAP expression was blocked by a nitric oxide synthase (NOS) inhibitor NMMA (Fig. 8F, G). Fourth, the LCN2-induced increase in cell death sensitivity was attenuated by NMMA (Fig. $8 \mathrm{H}$ ). SNP treatment alone also induced the typical morphological change that has been observed in LCN2-treated astrocytes (supplemental Fig. 5, available at www.jneurosci.org as supplemental material). In conjunction, these results suggest that $\mathrm{NO}$ production and LCN2 overexpression may form an amplification cycle at the upstream of astrocyte cell death, GFAP expression, and morphological changes.

\section{Role of Rho/ROCK pathway in the LCN2-induced morphological changes of astrocytes}

Because the Rho subfamily of small G-proteins has been previously implicated in the regulation of astrocyte morphology (Suidan et al., 1997; Ramakers and Moolenaar, 1998; John et al., 2004; Hall, 2005; Höltje et al., 2005; Chen et al., 2006; Borán and García, 2007), a possible involvement of Rho protein in the LCN2-induced morphological change of astrocytes was investigated. Rho/ROCK pathway appeared to play a pivotal role in regard to LCN2 actions on astrocyte morphology, based on the following results: (1) a ROCK inhibitor, Y27632, partly blocked LCN2-induced morphological changes (Fig. 9A,B); (2) Y27632 also inhibited the LCN2-induced GFAP expression (Fig. 9C,D); and (3) LCN2 induced Rho activation in astrocytes (Fig. 9E). Y27632 did not affect cell viability at the concentration used in the current study (data not shown). The LCN2-induced Rho activation was initiated at $1 \mathrm{~h}$ after LCN2 stimulation and sustained for $24 \mathrm{~h}$ (Fig. 9E). In contrast, Rac1 inhibition by the pharmacological inhibitor did not influence the LCN2 effects on astrocyte morphology (supplemental Fig. 6, available at www.jneurosci. org as supplemental material), indicating the specific role of Rho proteins in the LCN2-induced structural changes of astrocytes. The Rho/ROCK pathway, however, did not appear to be involved in the cell death-sensitizing effects of LCN2, because ROCK inhibition by Y27632 did not significantly influence the viability of LCN2-treated astrocytes (data not shown). Because cell migra-
Expression and functional analysis of $1 \mathrm{cn} 2$ in zebrafish model A zebrafish model was used to evaluate the expression of $1 \mathrm{cn} 2$ and its functional role in reactive astrocytosis in vivo. We first examined lcn2 expression in zebrafish CNS. The labeling of zebrafish embryos with anti-LCN2 polyclonal antibody produced no signals at $2 \mathrm{dpf}$ (data not shown), but $\mathrm{LCN} 2{ }^{+}$cells were evident in the forebrain and spinal cords at $3 \mathrm{dpf}$ (Fig. $11 A, B$ ). In the forebrain section, LCN2 antibody labeled microglia-like cells, which have morphology of microglia (Fig. $11 \mathrm{~A}$, arrows). This is consistent with a previous observation that all macrophages undergo specific phenotypic transformation into early microglia in the brain of $3 \mathrm{dpf}$ zebrafish embryos (Herbomel et al., 2001). Interestingly, in the spinal cords of 3 or $5 \mathrm{dpf}$ zebrafish embryos, LCN2 antibody labeled cells having radial glial characteristics, long radial processes from the central canal to the pial surface of spinal cords (Fig. $11 B, C$ ). To further investigate cell types marked by LCN2 antibody, we labeled spinal cord sections with the antiGFAP antibody, which is the marker for radial glia (Inagaki et al., 1994), together with the LCN2 antibody. All LCN2 ${ }^{+}$processes expressed GFAP, indicating that all $\mathrm{LCN}_{2}{ }^{+}$cells are actually radial glial cells in the spinal cord of zebrafish embryos (Fig. $11 C, D)$. To investigate the role of $1 \mathrm{cn} 2$ in radial glia development and morphology, we injected synthetic mRNA encoding rat LCN2 protein at the one-cell stage of $T g(g f a p-e g f p)$ embryos and labeled them with anti-Zrf-1 antibody, a marker for radial glial processes. Control zebrafish embryo did not receive any RNA injection as described in previous reports (Park et al., 2005; Maegawa et al., 2006; Hart et al., 2007). Because $T g(g f a p-e g f p)$ embryos express EGFP in radial glia under the control of a $g f a p$ promoter (Bernardos and Raymond, 2006), and anti-Zrf-1 antibody labels radial glial processes (Trevarrow et al., 1990), EGFP ${ }^{+}$ cell bodies (green) and $\mathrm{Zrf}-1^{+}$processes of radial glia (red) can be observed simultaneously (Fig. $11 E, G$ ). Consistent with in vitro findings (Fig. 6; supplemental Figs. 2-4, available at www. jneurosci.org as supplemental material), the number and thickness of ${\mathrm{Zrf}-1^{+}}^{+}$radial glia processes increased in most embryos injected with $\operatorname{lcn} 2$ mRNA, whereas the process length was not affected (Fig. 11F,H). Relative thickness, length, and number of cellular processes were quantified as described in Materials and Methods (Table 4). The process length may not be an appropriate 
A

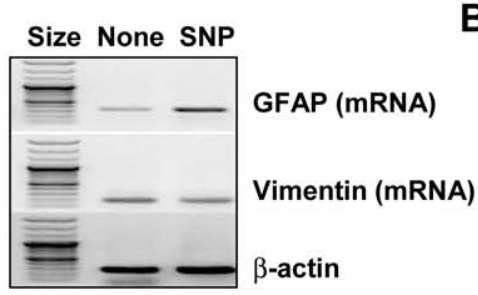

D

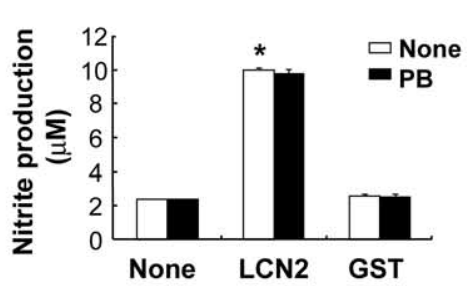

B



GFAP (protein)

Ponceau S
C

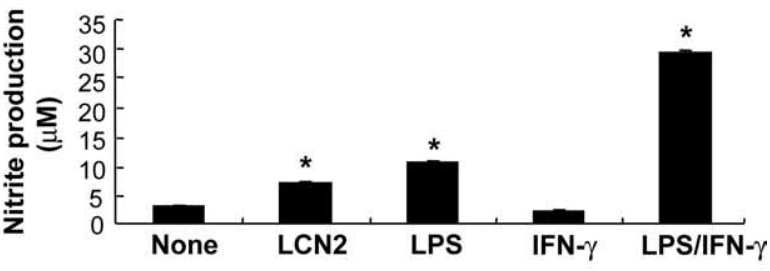

E

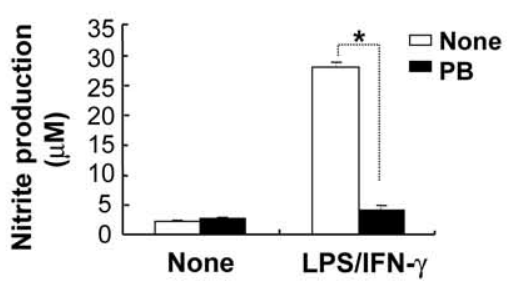

$F$

Size None LCN2 NMMA+LCN2

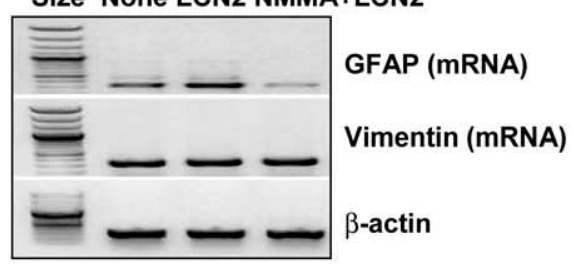

G None LCN2 NMMA+LCN2

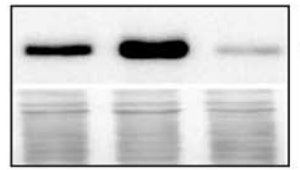

GFAP (protein)

Ponceau S

Figure 8. Involvement of NO in the LCN2 effects in astrocytes. After primary astrocytes were treated with SNP ( $0.5 \mathrm{~mm})$ for $24 \mathrm{~h}$, GFAP/vimentin mRNA or GFAP protein was detected by RT-PCR $(\boldsymbol{A})$ or Western blot analysis $(\boldsymbol{B})$, respectively. The expression of GFAP was significantly increased by SNP $(0.5 \mathrm{~mm})$ in primary astrocytes. Primary astrocytes were stimulated with recombinant $L C N 2$ protein $(10 \mu \mathrm{g} / \mathrm{ml})$, LPS $(100 \mathrm{ng} / \mathrm{ml})$, IFN $-\gamma(50 \mathrm{U} / \mathrm{ml})$, or a combination of LPS $(100 \mathrm{ng} / \mathrm{ml})$ and IFN $-\gamma(50 \mathrm{U} / \mathrm{ml})$ for $24 \mathrm{~h}$, and then nitrite production was assessed by Griess reagent $(\mathbf{C})$. ${ }^{*} p<0.05$ compared with no treatment. Primary astrocytes were also pretreated with polymyxin B (PB) $(10 \mu \mathrm{g} / \mathrm{ml})$ for 30 min before the treatment with LCN2 protein (10 $\mu \mathrm{g} / \mathrm{ml}), \mathrm{GST}$ protein ( $10 \mu \mathrm{g} / \mathrm{ml})(\boldsymbol{D})$, or a combination of LPS $(100 \mathrm{ng} / \mathrm{ml})$ and IFN- $\gamma(50 \mathrm{U} / \mathrm{ml})(\boldsymbol{E})$ for $24 \mathrm{~h}$, and then nitrite production was assessed by Griess reagent $(\boldsymbol{D}, \boldsymbol{E})$. ${ }^{*} p<0.05$ compared with untreated control $(\boldsymbol{C}, \boldsymbol{D})$ or as indicated $(\boldsymbol{E})$. Alternatively, primary astrocytes were treated with LCN2 protein (10 $\mu \mathrm{g} / \mathrm{ml})$ for $24 \mathrm{~h}$ or pretreated with NMMA (500 $\mu \mathrm{M})$ for $30 \mathrm{~min}$ before the treatment with recombinant LCN2 protein $(10 \mu \mathrm{g} / \mathrm{ml})$ for $24 \mathrm{~h}$. The expression of GFAP or vimentin was then detected by RT-PCR $(\boldsymbol{F})$ or Western blot analysis $(\boldsymbol{G})$ as indicated. After a similar treatment of primary astrocytes with LCN2 and NMMA in the presence of various cytotoxic agents $\left[\mathrm{H}_{2} \mathrm{O}_{2}(1 \mathrm{~mm})\right.$, paraquat (PQ) (100 $\left.\mu \mathrm{M}\right)$, SNP $(0.5 \mathrm{~mm})$, and LPS (100 ng/ml) plus IFN- $\gamma(50 \mathrm{U} / \mathrm{ml})$ for $\left.24 \mathrm{~h}\right]$, cell viability was assessed by MTT assay $(\boldsymbol{H})$. NMMA (500 $\mu \mathrm{m}$ ) alone did not exert any cytotoxicity (data not shown). Error bars indicate SD. The single asterisks indicate statistically significant differences between treatments with cytotoxic agents in the absence and presence of $L C N 2\left({ }^{*} p<0.05\right.$; None vs $L C N 2$; comparison 1$)$. The double asterisks indicate statistically significant differences between treatments with cytotoxic agents in the presence of LCN2 and NMMA plus LCN2 $\left({ }^{* *} p<0.05\right.$; LCN2 vs NMMA plus LCN2; comparison 2).

measure of phenotypic change of radial glia, because most glial processes extend from the central canal to the pial surface of spinal cords.

\section{Discussion}

In the current study, we have demonstrated that the astrocyte secretory protein LCN2 plays a dual role in determining the morphological and functional fate of activated astrocytes (Fig. 12). LCN2 sensitized activated astrocytes in regard to cell death and also induced a typical morphological change that is commonly observed in reactive astrocytosis in vivo. The bifunctional role of LCN2 was supported by the following evidence: (1) a forced increase or decrease in $1 \mathrm{cn} 2$ expression regulated cell death sensitivity of astrocytes positively or negatively, respectively; (2) recombinant LCN2 protein mimicked the effect of $1 \mathrm{cn} 2 \mathrm{cDNA}$ transfection or adenoviral expression; (3) lcn2 expression and secretion was induced by inflammatory stimuli in astrocytes; (4) LCN2 protein induced GFAP expression and morphological changes of astrocytes; and (5) lcn2 RNA injection induced morphological changes of radial glia cells in zebrafish models, consistent with in vitro findings. Based on these results, it is hypothesized that activated astrocytes may secrete LCN2 proteins under inflammatory conditions, which act in an autocrine manner to induce a morphological change of astrocytes and to sensitize activated astrocytes to cell death signals as a self-regulatory mech- anism. At the inflammatory sites in the CNS, the number of astrocytes may increase by proliferation or inward migration with a concurrent change in the cell morphology, which constitutes a typical phenotypic modulation associated with reactive astrocytosis. Astrocyte-derived LCN2 appears to be one of the major mediators determining the reactive astrocytosis phenotype. In addition, the secretion of LCN2 may be part of the autoregulatory mechanism, by which activated astrocytes in the inflammatory sites could be eliminated. Microglia may also participate in this process by secreting LCN2 proteins (Lee et al., 2007). These findings are in agreement with previous reports, which proposed the role of secreted LCN2/24p3 in the termination of the immune response in the peripheral system (Devireddy et al., 2001) as well as in the CNS (Lee et al., 2007). Moreover, it has been previously reported that the production of erythroid and monocyte/macrophage lineage cells is also under the control of LCN2 in a similar manner to our findings (Miharada et al., 2005, 2008). LCN2 acted as an autocrine factor that suppressed the growth of erythroid and monocyte/macrophage lineage cells by inducing apoptosis and inhibiting differentiation.

In response to all forms of CNS insults, astrocytes become reactive and undergo the process termed reactive astrocytosis (Sofroniew, 2005). In this process, astrocytes proceed through proliferation and morphological changes, and experience the up- 
A

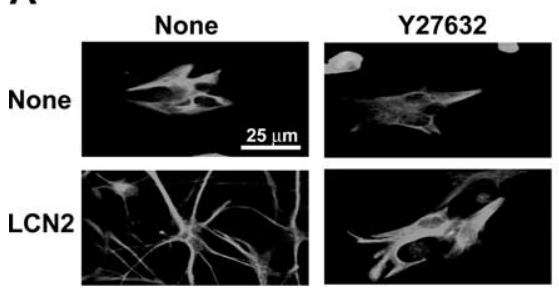

C

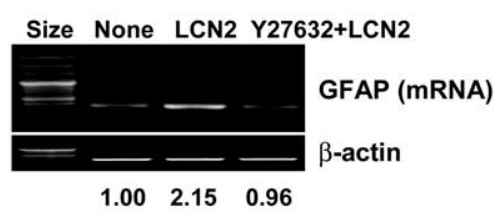

E

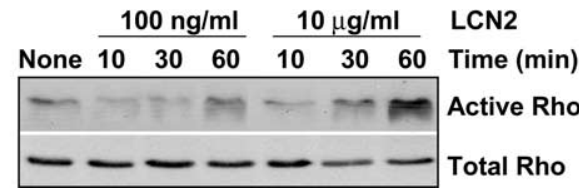

B

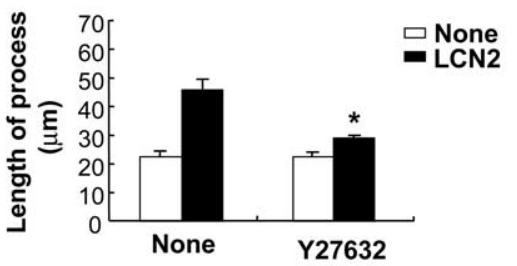

D

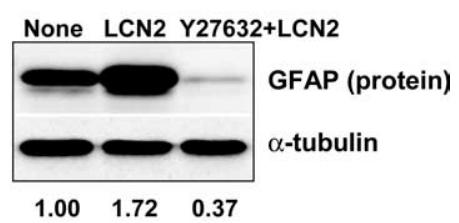

Figure 9. Role of Rho/ROCK pathway in the LCN2-induced morphological changes of astrocytes. Primary astrocytes were pretreated with Y27632 (ROCK inhibitor; $100 \mu \mathrm{m}$ ) in the absence or presence of recombinant LCN2 protein (10 $\mu \mathrm{g} / \mathrm{ml})$ for $24 \mathrm{~h}$. Cells were double-stained for GFAP (green) and Hoechst 33342 (cell nuclei; blue) (magnification, $\times 400)(\boldsymbol{A})$. Measurement of the length of the longest astrocyte processes for each treatment was done $(\boldsymbol{B})$. Error bars indicate SD. ${ }^{*} p<0.05$ compared with LCN2 treatment alone. GFAP mRNA $(\boldsymbol{C})$ or protein levels $(\boldsymbol{D})$ were also evaluated by RT-PCR or Western blot analysis, respectively, after stimulation with LCN2 in the absence or presence of Rho kinase inhibitor Y27632 (100 $\mu \mathrm{M})$ for $24 \mathrm{~h}$. $\beta$-Actin or $\alpha$-tubulin was detected to confirm the equal loading of the samples. Results of densitometric analysis are shown below $(\boldsymbol{C}, \boldsymbol{D})$. After primary astrocytes were treated with LCN2 protein ( $100 \mathrm{ng} / \mathrm{ml}$ or $10 \mu \mathrm{g} / \mathrm{ml}$ ) for the indicated time periods or $24 \mathrm{~h}$, the activation state of Rho was assessed by a pulldown assay $(\boldsymbol{E})$. The results are representative of three or more independent experiments.

regulation of intermediate filaments such as GFAP. Although reactive astrocytosis has been commonly observed under various pathological conditions, the molecular mechanisms underlying the reactive astrocytic phenotype are not well understood. Our current study suggests that LCN2 protein secreted from astrocytes themselves may mediate this phenotypic change. The involvement of $1 \mathrm{cn} 2$ in the phenotypic change of cell morphology has been previously reported. lcn2 was an endogenous epithelial inducer (Yang et al., 2002) and stimulated the epithelial phenotype of transformed cells (Hanai et al., 2005; Lee et al., 2006). lcn2 also promoted tubulogenesis by regulating epithelial morphogenesis (Gwira et al., 2005). Although the role of $l \mathrm{cn} 2$ as an epithelial inducer as related to the effects of $\operatorname{lcn} 2$ on the astrocyte morphology found in the present study is not currently understood, it is evident that $1 \mathrm{cn} 2$ has an important role in determining cellular morphology. A central role of LCN2 protein secreted under inflammatory conditions in the control of astrocyte morphology was supported by LCN2 neutralization experiments. When LCN2 was neutralized by adding anti-LCN2 antibody into astrocyte cultures exposed to strong inflammatory stimuli such as LPS and IFN- $\gamma$, the induction of morphological changes was partially abrogated (S. Lee and K. Suk, un-
A

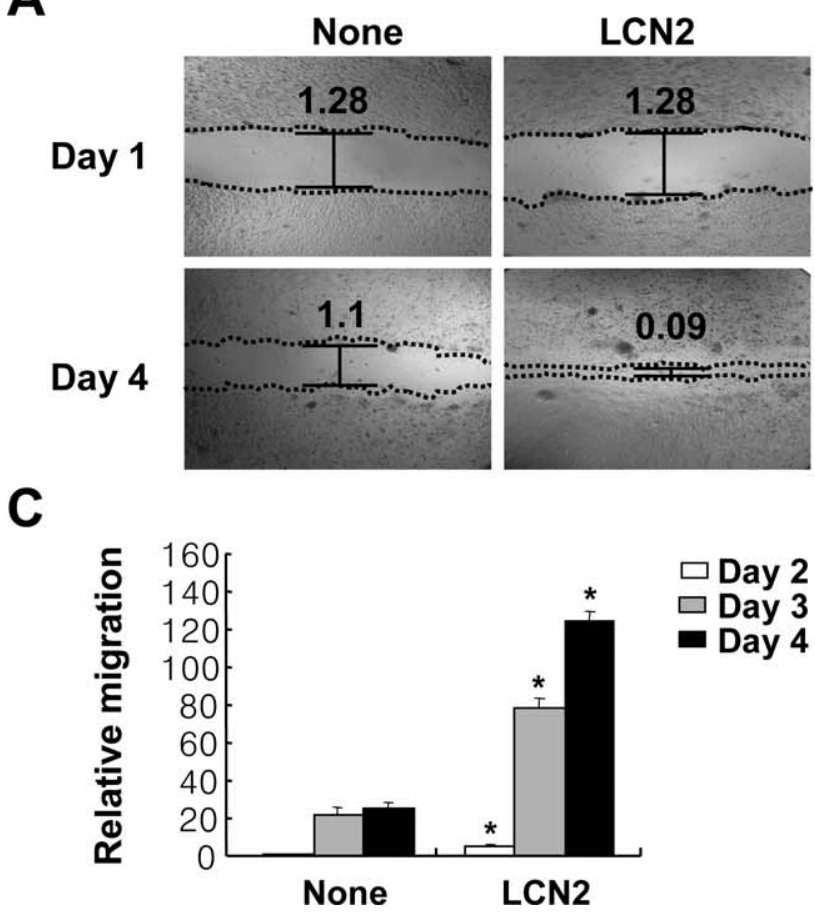

B
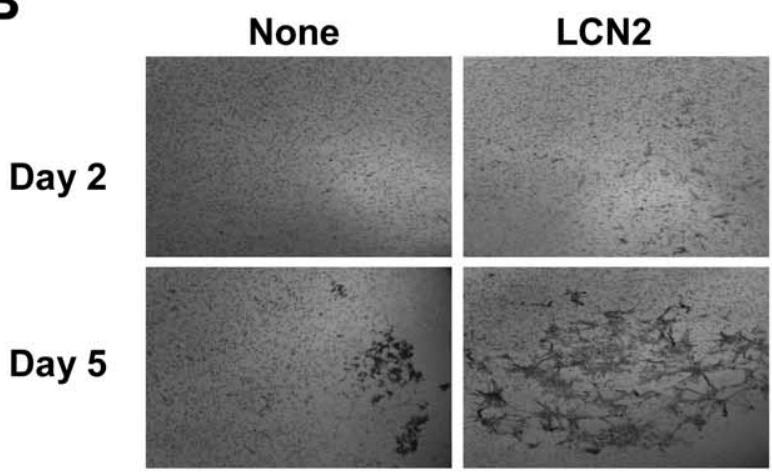

D

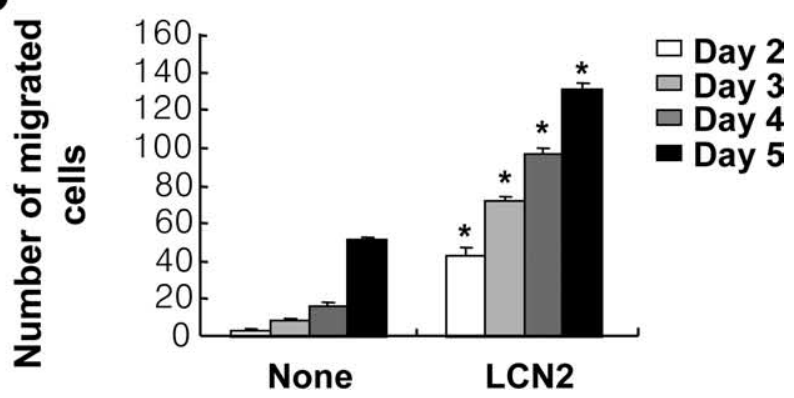

Figure 10. Stimulation of astrocyte migration by LCN2. Primary astrocytes were treated with recombinant LCN2 protein $(10 \mu \mathrm{g} / \mathrm{ml})$ for the indicated time periods, and then either wound healing assay $(\boldsymbol{A})$ or Boyden chamber assay $(\boldsymbol{B})$ was performed to evaluate cell migration (magnification, $\times 100)$. Quantification of astrocyte migration was conducted after wound healing assay $(\boldsymbol{C})$ or Boyden chamber assay $(\boldsymbol{D})$. Error bars indicate SD. ${ }^{*} p<0.05$ compared with untreated control at the same day. 

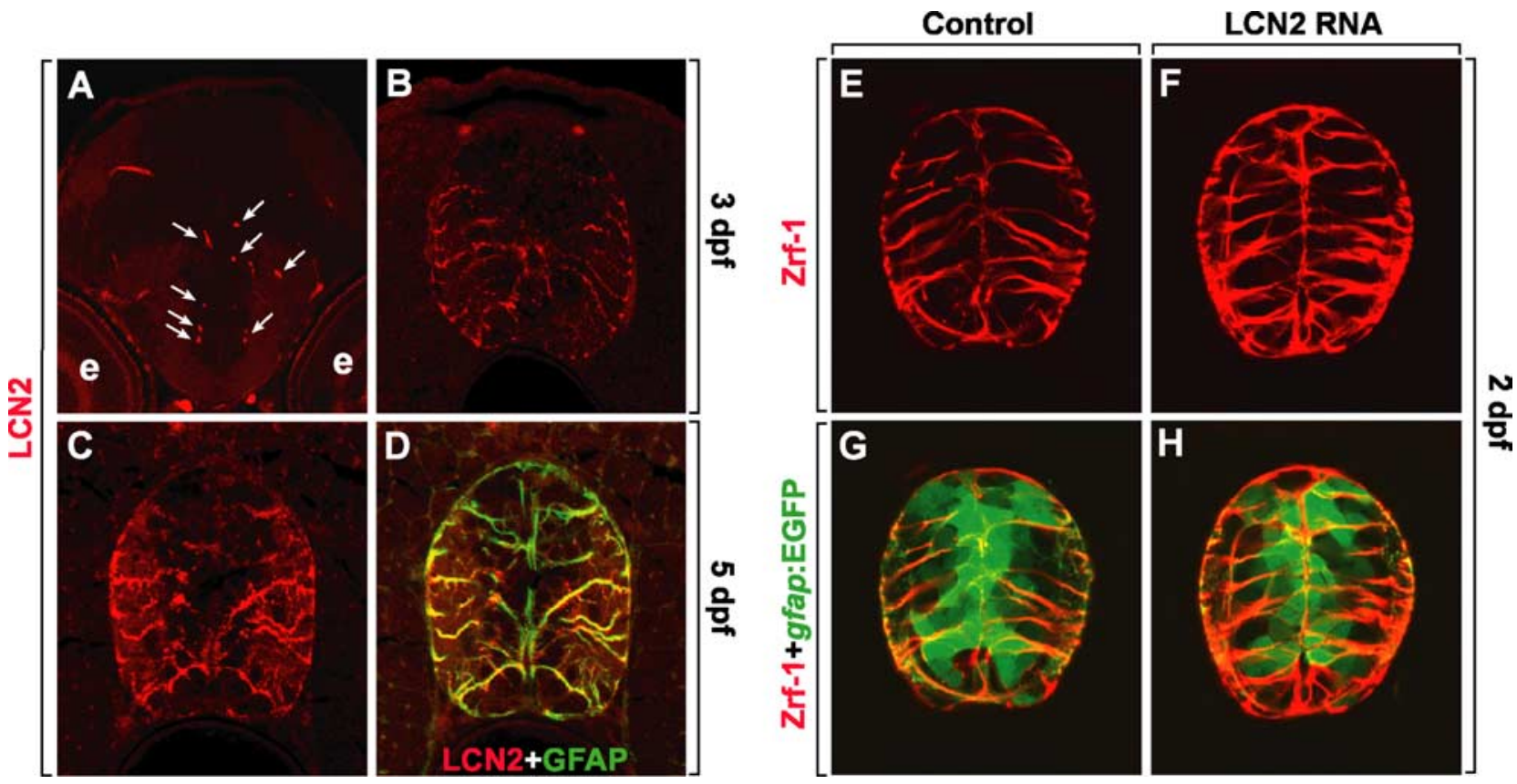

Figure 11. Expression of $\mathrm{I} \mathrm{cn} 2$ in spinal cord of zebrafish embryos and its functional role in determination of radial glia morphology. $A-D$, Anti-LCN2 antibody labeled radial glia in the spinal cord of zebrafish embryos. All images are transverse sections of zebrafish CNS, labeled by anti-LCN2 antibody, dorsal to top. $A, B, L C N 2$ antibody labeled microglia-like cells in forebrain ( $A$, arrows) and radial glia in spinal cord at $3 \mathrm{dpf}(\boldsymbol{B})$. The "e" indicates an eye. $\boldsymbol{C}, \boldsymbol{D}$, Double labeling of spinal cord with anti-LCN2 (red) and -GFAP antibodies (green) at 5 dpf ( $\boldsymbol{C}, \boldsymbol{D}$, same section). LCN2 was expressed in the GFAP ${ }^{+}$radial glia. $\boldsymbol{E}-\boldsymbol{H}, 0$ verexpression of rat lcn2 increased the number and thickness of radial glial processes. All images are transverse sections of spinal cord of $T g$ ( gfap:egfp) embryos, dorsal upward. Anti-Zrf-1 antibody labeling $(\boldsymbol{E}, \boldsymbol{F})$ and combined anti-Zrf-1 (red) and gfap:EGFP (green) images of the same sections $(\boldsymbol{G}, \boldsymbol{H})$ of control embryo which did not receive any RNA injection $(\boldsymbol{E}, \boldsymbol{G})$ and Icn2 RNA-injected embryo $(\boldsymbol{F}, \boldsymbol{H})$.

Table 4. Effects of LCN2 on radial glia processes in zebrafish

\begin{tabular}{lrc}
\hline & Control group & \multicolumn{1}{l}{$\begin{array}{l}\text { Ln2 RNA injection } \\
\text { group }\end{array}$} \\
\hline Thickness of process & $0.32 \pm 0.02$ & $0.32 \pm 0.02^{*}$ \\
Length of process & $3.42 \pm 0.09$ & $3.65 \pm 0.09$ \\
Number of process & $23.20 \pm 0.48$ & $34.60 \pm 1.21^{* *}$ \\
\hline
\end{tabular}

The relative thickness, length, and number of processes of zebrafish radial glia cells were quantified as follows: the five longest or thickest cellular processes for each section were measured. The total number of processes was also counted for each section. Seven zebrafish sections for each treatment were quantified. The results were normalized to the diameter of the spinal cord [(vertical diameter + horizontal diameter $) / 2)]$ and presneted as mean \pm SEM $(n$ $=7) .{ }^{*} p<0.01$, ${ }^{* *} p<0.001$, compared with control group.

published data). Understanding the mechanisms involved in controlling astrocyte morphology is fundamental in the CNS research, because astrocytes interact with neurons and other cells in contact through their processes that are most probably influenced by the cell shape. Therefore, additional studies are necessary to gain a better understanding as to how $1 \mathrm{cn} 2$ participates in the control of astrocyte morphology and interaction with neurons and other glia cell types in the CNS.

The Rho family of small G-proteins has been frequently involved in structural changes of astrocytes (Suidan et al., 1997; Ramakers and Moolenaar, 1998; Avalos et al., 2004; John et al., 2004; Höltje et al., 2005; Chen et al., 2006; Osmani et al., 2006; Borán and García, 2007) and other cell types (Takai et al., 2001; Etienne-Manneville and Hall, 2002; Heo and Meyer, 2003; Hall, 2005). Previously, it was demonstrated that RhoA negatively regulated astrocyte stellation (Suidan et al., 1997; Abe and Misawa, 2003; Chen et al., 2006; Burgos et al., 2007), migration (Höltje et al., 2005), and the IL- $1 \beta$-induced reactive astroglial phenotype (John et al., 2004). RhoA activation was, however, required for Thy-1-induced morphological changes in astrocytes that resembled those in brain injuries (Avalos et al., 2004). $\operatorname{lcn} 2$, in the current study, stimulated the growth of astrocyte pro- cesses and locomotive activity by activating Rho and ROCK pathway. Although discrepancies regarding the role of Rho/ROCK pathway in the astrocyte morphology cannot be fully explained, it is speculated that lcn2 may use additional signaling pathways in parallel with or downstream of Rho/ROCK pathway to induce morphological changes. Opposing roles of Rho proteins in the motility of astrocytes have been reported. In most studies, Rho activation has been associated with an increased migratory activity of astrocytes (John et al., 2004) and other cell types (Raftopoulou and Hall, 2004; Hall, 2005), which is consistent with our results. Moreover, Erschbamer et al. (2005) reported that GFAPimmunoreactive reactive astrocytes showed a marked increase of RhoA expression after spinal cord injuries, supporting the promigratory activity of Rho in reactive astrocytes. In contrast, the inhibition of Rho activities promoted astrocyte migration in a few reports (Höltje et al., 2005; Borán and García, 2007), in which the role of Rho in astrocytes may contrast with Rho-dependent mechanisms in other cell types. The Rho protein is a central regulator of cell morphology, contractility, and migration. Rho controls cell motility through the formation of stress fiber and focal adhesion. Cell motility is generally described as a cyclical process divided into alternating phases of protrusion and contraction (Pellegrin and Mellor, 2007). Based on the contractile nature of stress fibers, they are thought to provide a contractile force for cell migration (Kreis and Birchmeier, 1980). However, stress fibers inhibited cell migration in other studies, arguing against the role of Rho and stress fibers in cell motility (Couchman and Rees, 1979; Pellegrin and Mellor, 2007). Moreover, the coordinated regulation of the Rho protein family including Rho, Rac, and Cdc42, rather than a single Rho protein, is believed to be important in the control of cell behavior. Thus, the role of Rho proteins in the regulation of cell behavior (such as morphology, migration, etc.) appears to depend on triggering signals, cellular con- 


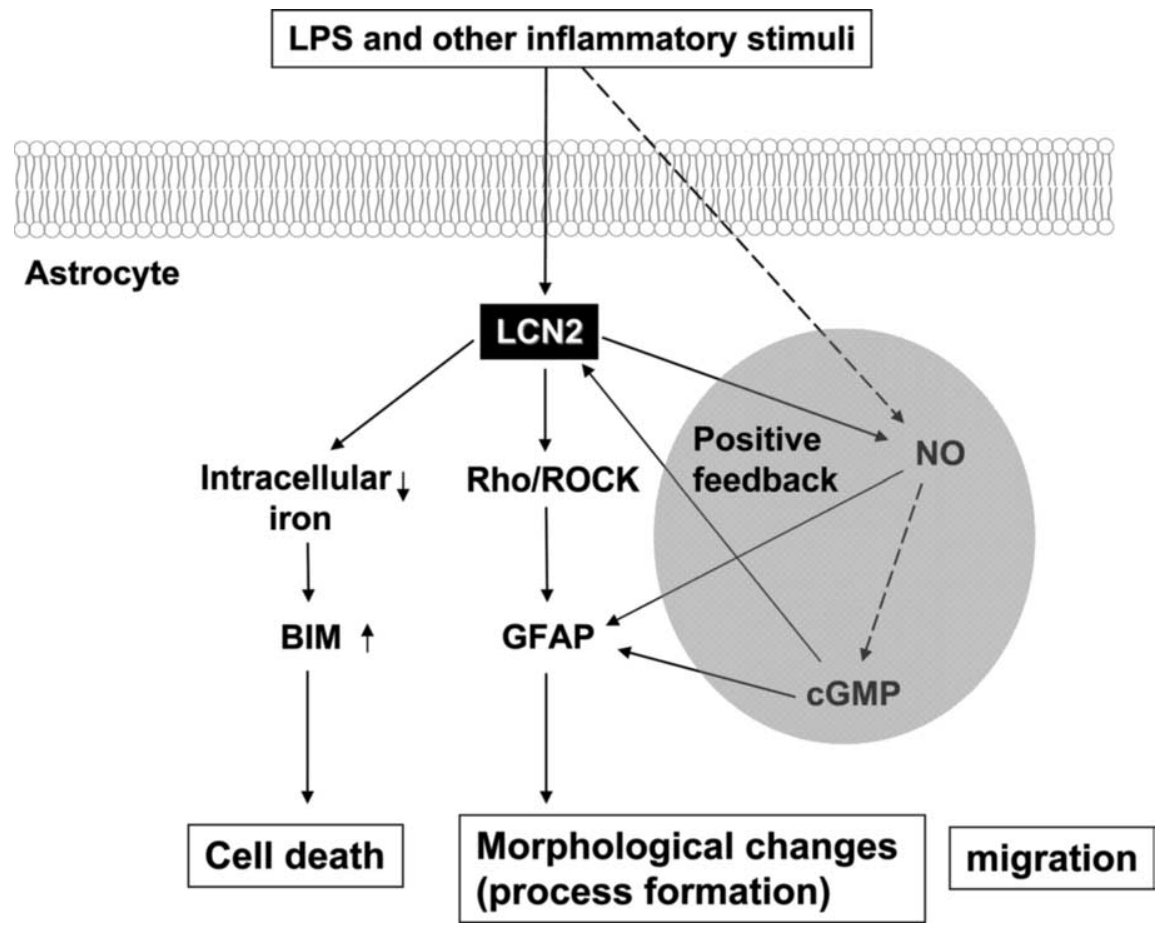

Figure 12. Schematic diagram showing the bifunctional role of $L C N 2$ in cell death and morphological changes of astrocytes. Reactive astrocytes under inflammatory condition secrete $\mathrm{ln} 2$, which may feed back on astrocytes to induce morphological as well as functional changes. Icn2 induces morphological changes of reactive astrocytes and promotes their migration through the Rho-ROCK pathway. Icn2 also renders astrocytes more sensitive to cell death signals by regulating iron metabolism and Bim pathway, which may provide a basis for the self-regulatory elimination of reactive astrocytes in vivo. N0 and cGMP appear to form a positive feedback loop that amplifies the Inn2-Rho-ROCK-GFAP pathway. The morphological changes of astrocytes appear to be closely related with the phenotypic changes into cell death-prone astrocytes.

texts, and microenvironments under which cells are poised. In renal and cardiovascular systems, the RhoA/ROCK signal is related to inflammation, proliferation, migration, oxidative stress, matrix production, and tissue injury, which are in good agreement with our results. However, NO-cGMP signal is counterregulatory against RhoA/ROCK and antiinflammatory and organ protective (Oka et al., 2008), which is the opposite of the current findings in glia. These differences might be related to NOS isozymes expressed in different organs. Y27632 has been previously shown to have significant effects on morphology in rat astrocytes when used alone at lower concentrations than that used here (Honjo et al., 2001). However, no significant changes in morphology were observed after Y27632 treatment of mouse astrocytes in the current study. The discrepancy may be attributable to species difference.

The results reported here were obtained by using cultured astrocytes and zebrafish models. The functional significance of $\operatorname{lcn} 2$ in regard to astrocyte cell death and morphological change in vivo needs to be further examined in the mammalian system. Although lcn2 expression has been detected in a wide variety of tissues, its expression and role in the CNS has been addressed by few studies so far. Recently, genome-wide expression profiling has shown that LCN2 is upregulated in mouse brain tissues after focal cerebral ischemia (Trendelenburg et al., 2002; MacManus et al., 2004). The expression of lcn 2 was also detected in the choroid plexus of mice (Marques et al., 2008). Additional investigations are necessary as to whether astrocytes are the major cellular sources of $1 \mathrm{cn} 2$ in mammalian brains in vivo. Nevertheless, in the current study, lcn2 expression was detected in radial glia cells of spinal cord and microglia-like cells in the brains of developing zebrafish. Radial glial cells, which later transform into astrocytes, were the major cell types expressing lcn2 (see below).

Zebrafish became an important model organism for biomedical research over the last few decades. Zebrafish traditionally used for the analysis of basic developmental processes is now widely used as alternative animal models for human disease and drug discovery purposes (Kari et al., 2007; Lieschke and Currie, 2007). Expression patterns and functional analysis of $1 \mathrm{cn} 2$ in zebrafish revealed that $\operatorname{lcn} 2$ is strongly and uniquely expressed in radial glia cells, and induces morphological changes of glia in vivo similar to those observed in cultured glia cells. Radial glial cells are believed to play a pivotal role in the developing CNS; they are involved in key developmental processes, ranging from patterning and neuronal migration to neurogenesis. Radial glial cells have long radial processes extending from the ventricular zone to the pial surface, and possess glial properties such as the content of glycogen granules or the expression of astrocyte-specific glutamate transporters and GFAP. After neurogenesis and migration processes are completed, most radial glia cells transform into astrocytes (Barry and McDermott, 2005; Stipursky and Gomes, 2007). Thus, the expression of $1 \mathrm{cn} 2$ in zebrafish radial glia cells and the effect of exogenous lcn2 expression on the radial glia processes (Fig. 11) strongly support the crucial role of $\ln 2$ in reactive astrocytosis in vivo. Previously, megalin expression in zebrafish was restricted to pronephros region (Anzenberger et al., 2006), arguing against that LCN2 protein may have been trapped by megalin-expressing cells.

In conclusion, we present evidence that the secretory protein LCN2 is involved in the morphological transformation and cell death of reactive astrocytes (Fig. 12). The morphological change of astrocytes and their vulnerability to cell death appear to be closely related phenotypes. Activated astrocytes in vivo may secrete LCN2 proteins not only to induce morphological transformation associated with reactive astrocytosis but also to promote cell death. This can be a self-regulatory mechanism by which activated astrocytes are sensitized to cell death signals in the CNS inflammation: on inflammatory stimulation astrocyte population expanded either by recruitment or proliferation may need to be under feedback control. The morphological transformation of astrocytes may facilitate the self-regulatory mechanism. However, the exact molecular mechanisms underlying the bifunctional role of $\operatorname{lcn} 2$ remain to be elucidated in future studies. Moreover, it is not clear at present what aspects are shared and what are distinct between the lcn2-initiated cell death cascade and morphological cascade. Nevertheless, our data suggest that $\operatorname{lcn} 2$ can be used as a drug target for the therapeutic manipulation of reactive astrocytosis and deleterious events that are associated with it.

\section{References}

Abe K, Misawa M (2003) Astrocyte stellation induced by Rho kinase inhibitors in culture. Brain Res Dev Brain Res 143:99-104. 
Anzenberger U, Bit-Avragim N, Rohr S, Rudolph F, Dehmel B, Willnow TE, Abdelilah-Seyfried S (2006) Elucidation of megalin/LRP2-dependent endocytic transport processes in the larval zebrafish pronephros. J Cell Sci 119:2127-2137.

Aschner M (1998) Astrocytes as mediators of immune and inflammatory responses in the CNS. Neurotoxicology 19:269-281.

Avalos AM, Arthur WT, Schneider P, Quest AF, Burridge K, Leyton L (2004) Aggregation of integrins and RhoA activation are required for Thy-1-induced morphological changes in astrocytes. J Biol Chem 279:39139-39145.

Barres BA, Barde Y (2000) Neuronal and glial cell biology. Curr Opin Neurobiol 10:642-648.

Barry D, McDermott K (2005) Differentiation of radial glia from radial precursor cells and transformation into astrocytes in the developing rat spinal cord. Glia 50:187-197.

Bassi R, Giussani P, Anelli V, Colleoni T, Pedrazzi M, Patrone M, Viani P, Sparatore B, Melloni E, Riboni L (2008) HMGB1 as an autocrine stimulus in human T98G glioblastoma cells: role in cell growth and migration. J Neurooncol 87:23-33.

Bernardos RL, Raymond PA (2006) GFAP transgenic zebrafish. Gene Expr Patterns 6:1007-1013.

Borán MS, García A (2007) The cyclic GMP-protein kinase G pathway regulates cytoskeleton dynamics and motility in astrocytes. J Neurochem 102:216-230.

Borregaard N, Cowland JB (2006) Neutrophil gelatinase-associated lipocalin, a siderophore-binding eukaryotic protein. Biometals 19:211-215.

Boukhelifa M, Hwang SJ, Valtschanoff JG, Meeker RB, Rustioni A, Otey CA (2003) A critical role for palladin in astrocyte morphology and response to injury. Mol Cell Neurosci 23:661-668.

Brahmachari S, Fung YK, Pahan K (2006) Induction of glial fibrillary acidic protein expression in astrocytes by nitric oxide. J Neurosci 26:4930-4939.

Burgos M, Calvo S, Molina F, Vaquero CF, Samarel A, Llopis J, Tranque P (2007) PKCepsilon induces astrocyte stellation by modulating multiple cytoskeletal proteins and interacting with Rho A signalling pathways: implications for neuroinflammation. Eur J Neurosci 25:1069-1078.

Chen CJ, Ou YC, Lin SY, Liao SL, Huang YS, Chiang AN (2006) L-Glutamate activates RhoA GTPase leading to suppression of astrocyte stellation. Eur J Neurosci 23:1977-1987.

Correa-Cerro LS, Mandell JW (2007) Molecular mechanisms of astrogliosis: new approaches with mouse genetics. J Neuropathol Exp Neurol 66:169-176.

Couchman JR, Rees DA (1979) The behaviour of fibroblasts migrating from chick heart explants: changes in adhesion, locomotion and growth, and in the distribution of actomyosin and fibronectin. J Cell Sci 39:149-165.

Cowland JB, Sørensen OE, Sehested M, Borregaard N (2003) Neutrophil gelatinase-associated lipocalin is up-regulated in human epithelial cells by IL-1 $\beta$, but not by TNF- $\alpha$. J Immunol 171:6630-6639.

Devireddy LR, Teodoro JG, Richard FA, Green MR (2001) Induction of apoptosis by a secreted lipocalin that is transcriptionally regulated by IL-3 deprivation. Science 293:829-834.

Devireddy LR, Gazin C, Zhu X, Green MR (2005) A cell-surface receptor for lipocalin $24 \mathrm{p} 3$ selectively mediates apoptosis and iron uptake. Cell 123:1293-1305.

Erschbamer MK, Hofstetter CP, Olson L (2005) RhoA, RhoB, RhoC, Racl, Cdc42, and Tc10 mRNA levels in spinal cord, sensory ganglia, and corticospinal tract neurons and long-lasting specific changes following spinal cord injury. J Comp Neurol 484:224-233.

Etienne-Manneville S, Hall A (2002) Rho GTPases in cell biology. Nature 420:629-635.

Falsig J, Latta M, Leist M (2004) Defined inflammatory states in astrocyte cultures: correlation with susceptibility towards CD95-driven apoptosis. J Neurochem 88:181-193.

Farina C, Aloisi F, Meinl E (2007) Astrocytes are active players in cerebral innate immunity. Trends Immunol 28:138-145.

Ferrari D, Chiozzi P, Falzoni S, Dal Susino M, Collo G, Buell G, Di Virgilio F (1997) ATP-mediated cytotoxicity in microglial cells. Neuropharmacology 36:1295-1301.

Flo TH, Smith KD, Sato S, Rodriguez DJ, Holmes MA, Strong RK, Akira S, Aderem A (2004) Lipocalin 2 mediates an innate immune response to bacterial infection by sequestrating iron. Nature 432:917-921.

Flower DR, North AC, Sansom CE (2000) The lipocalin protein family: structural and sequence overview. Biochim Biophys Acta 1482:9-24.

Gwira JA, Wei F, Ishibe S, Ueland JM, Barasch J, Cantley LG (2005) Expres- sion of neutrophil gelatinase-associated lipocalin regulates epithelial morphogenesis in vitro. J Biol Chem 280:7875-7882.

Hall A (2005) Rho GTPases and the control of cell behaviour. Biochem Soc Trans 33:891-895.

Hanai J, Mammoto T, Seth P, Mori K, Karumanchi SA, Barasch J, Sukhatme VP (2005) Lipocalin 2 diminishes invasiveness and metastasis of Rastransformed cells. J Biol Chem 280:13641-13647.

Hart DO, Raha T, Lawson ND, Green MR (2007) Initiation of zebrafish haematopoiesis by the TATA-box-binding protein-related factor Trf3. Nature 450:1082-1085.

Heo WD, Meyer T (2003) Switch-of-function mutants based on morphology classification of Ras superfamily small GTPases. Cell 113:315-328.

Herbomel P, Thisse B, Thisse C (2001) Zebrafish early macrophages colonize cephalic mesenchyme and developing brain, retina, and epidermis through a M-CSF receptor-dependent invasive process. Dev Biol 238:274-288.

Höltje M, Hoffmann A, Hofmann F, Mucke C, Grosse G, Van Rooijen N, Kettenmann H, Just I, Ahnert-Hilger G (2005) Role of Rho GTPase in astrocyte morphology and migratory response during in vitro wound healing. J Neurochem 95:1237-1248.

Honjo M, Tanihara H, Inatani M, Kido N, Sawamura T, Yue BY, Narumiya S, Honda Y (2001) Effects of rho-associated protein kinase inhibitor Y-27632 on intraocular pressure and outflow facility. Invest Ophthalmol Vis Sci 42:137-144.

Hu J, Van Eldik LJ (1996) S100 beta induces apoptotic cell death in cultured astrocytes via a nitric oxide-dependent pathway. Biochim Biophys Acta 1313:239-245.

Hu W, Onuma T, Birukawa N, Abe M, Ito E, Chen Z, Urano A (2008) Change of morphology and cytoskeletal protein gene expression during dibutyryl cAMP-induced differentiation in C6 glioma cells. Cell Mol Neurobiol 28:519-528.

Hvidberg V, Jacobsen C, Strong RK, Cowland JB, Moestrup SK, Borregaard N (2005) The endocytic receptor megalin binds the iron transporting neutrophil-gelatinase-associated lipocalin with high affinity and mediates its cellular uptake. FEBS Lett 579:773-777.

Inagaki M, Nakamura Y, Takeda M, Nishimura T, Inagaki N (1994) Glial fibrillary acidic protein: dynamic property and regulation by phosphorylation. Brain Pathol 4:239-243.

John GR, Chen L, Rivieccio MA, Melendez-Vasquez CV, Hartley A, Brosnan CF (2004) Interleukin- $1 \beta$ induces a reactive astroglial phenotype via deactivation of the Rho GTPase-Rock axis. J Neurosci 24:2837-2845.

Jones LL, Banati RB, Graeber MB, Bonfanti L, Raivich G, Kreutzberg GW (1997) Population control of microglia: does apoptosis play a role? J Neurocytol 26:755-770.

Jou I, Lee JH, Park SY, Yoon HJ, Joe EH, Park EJ (2006) Gangliosides trigger inflammatory responses via TLR4 in brain glia. Am J Pathol 168:1619-1630.

Kari G, Rodeck U, Dicker AP (2007) Zebrafish: an emerging model system for human disease and drug discovery. Clin Pharmacol Ther 82:70-80.

Kim HJ, Tsoy I, Park MK, Lee YS, Lee JH, Seo HG, Chang KC (2006) Iron released by sodium nitroprusside contributes to heme oxygenase-1 induction via the cAMP-protein kinase A-mitogen-activated protein kinase pathway in RAW 264.7 cells. Mol Pharmacol 69:1633-1640.

Kim JY, Ahn HJ, Ryu JH, Suk K, Park JH (2004) BH3-only protein Noxa is a mediator of hypoxic cell death induced by hypoxia-inducible factor 1alpha. J Exp Med 199:113-124.

Kim S, Ock J, Kim AK, Lee HW, Cho JY, Kim DR, Park JY, Suk K (2007) Neurotoxicity of microglial cathepsin D revealed by secretome analysis. J Neurochem 103:2640-2650.

Kim S, Hwang J, Lee WH, Hwang DY, Suk K (2008) Role of protein kinase Cdelta in paraquat-induced glial cell death. J Neurosci Res 86:2062-2070.

Kingham PJ, Pocock JM (2000) Microglial apoptosis induced by chromogranin $\mathrm{A}$ is mediated by mitochondrial depolarisation and the permeability transition but not by cytochrome $c$ release. J Neurochem 74:1452-1462.

Kjeldsen L, Cowland JB, Borregaard N (2000) Human neutrophil gelatinase-associated lipocalin and homologous proteins in rat and mouse. Biochim Biophys Acta 1482:272-283.

Kreis TE, Birchmeier W (1980) Stress fiber sarcomeres of fibroblasts are contractile. Cell 22:555-561.

Kucenas S, Takada N, Park HC, Woodruff E, Broadie K, Appel B (2008) CNS-derived glia ensheath peripheral nerves and mediate motor root development. Nat Neurosci 11:143-151.

Lee HJ, Lee EK, Lee KJ, Hong SW, Yoon Y, Kim JS (2006) Ectopic expression 
of neutrophil gelatinase-associated lipocalin suppresses the invasion and liver metastasis of colon cancer cells. Int J Cancer 118:2490-2497.

Lee J, Hur J, Lee P, Kim JY, Cho N, Kim SY, Kim H, Lee MS, Suk K (2001) Dual role of inflammatory stimuli in activation-induced cell death of mouse microglial cells: initiation of two separate apoptotic pathways via induction of interferon regulatory factor-1 and caspase-11. J Biol Chem 276:32956-32965.

Lee P, Lee J, Kim S, Lee MS, Yagita H, Kim SY, Kim H, Suk K (2001) NO as an autocrine mediator in the apoptosis of activated microglial cells: correlation between activation and apoptosis of microglial cells. Brain Res 892:380-385.

Lee S, Lee J, Kim S, Park JY, Lee WH, Mori K, Kim SH, Kim IK, Suk K (2007) A dual role of lipocalin 2 in the apoptosis and deramification of activated microglia. J Immunol 179:3231-3241.

Lieschke GJ, Currie PD (2007) Animal models of human disease: zebrafish swim into view. Nat Rev Genet 8:353-367.

Lin J, Cai W (2004) Effect of vimentin on reactive gliosis: in vitro and in vivo analysis. J Neurotrauma 21:1671-1682.

Liu B, Wang K, Gao HM, Mandavilli B, Wang JY, Hong JS (2001) Molecular consequences of activated microglia in the brain: overactivation induces apoptosis. J Neurochem 77:182-189.

Liu Q, Nilsen-Hamilton M (1995) Identification of a new acute phase protein. J Biol Chem 270:22565-22570.

Mabuchi T, Kitagawa K, Ohtsuki T, Kuwabara K, Yagita Y, Yanagihara T, Hori M, Matsumoto M (2000) Contribution of microglia/macrophages to expansion of infarction and response of oligodendrocytes after focal cerebral ischemia in rats. Stroke 31:1735-1743.

MacManus JP, Graber T, Luebbert C, Preston E, Rasquinha I, Smith B, Webster J (2004) Translation-state analysis of gene expression in mouse brain after focal ischemia. J Cereb Blood Flow Metab 24:657-667.

Maegawa S, Varga M, Weinberg ES (2006) FGF signaling is required for $\beta$-catenin-mediated induction of the zebrafish organizer. Development 133:3265-3276.

Marques F, Rodrigues AJ, Sousa JC, Coppola G, Geschwind DH, Sousa N, Correia-Neves M, Palha JA (2008) Lipocalin 2 is a choroid plexus acutephase protein. J Cereb Blood Flow Metab 28:450-455.

McCarthy KD, de Vellis J (1980) Preparation of separate astroglial and oligodendroglial cell cultures from rat cerebral tissue. J Cell Biol 85:890-902.

Meheus LA, Fransen LM, Raymackers JG, Blockx HA, Van Beeumen JJ, Van Bun SM, Van de Voorde A (1993) Identification by microsequencing of lipopolysaccharide-induced proteins secreted by mouse macrophages. J Immunol 151:1535-1547.

Miharada K, Hiroyama T, Sudo K, Nagasawa T, Nakamura Y (2005) Lipocalin 2 functions as a negative regulator of red blood cell production in an autocrine fashion. FASEB J 19:1881-1883.

Miharada K, Hiroyama T, Sudo K, Danjo I, Nagasawa T, Nakamura Y (2008) Lipocalin 2-mediated growth suppression is evident in human erythroid and monocyte/macrophage lineage cells. J Cell Physiol 215:526-537.

Mishra J, Mori K, Ma Q, Kelly C, Yang J, Mitsnefes M, Barasch J, Devarajan P (2004) Amelioration of ischemic acute renal injury by neutrophil gelatinase-associated lipocalin. J Am Soc Nephrol 15:3073-3082.

Mori K, Nakao K (2007) Neutrophil gelatinase-associated lipocalin as the real-time indicator of active kidney damage. Kidney Int 71:967-970.

Mori K, Lee HT, Rapoport D, Drexler IR, Foster K, Yang J, Schmidt-Ott KM, Chen X, Li JY, Weiss S, Mishra J, Cheema FH, Markowitz G, Suganami T, Sawai K, Mukoyama M, Kunis C, D'Agati V, Devarajan P, Barasch J (2005) Endocytic delivery of lipocalin-siderophore-iron complex rescues the kidney from ischemia-reperfusion injury. J Clin Invest 115:610-621.

Nelson AM, Zhao W, Gilliland KL, Zaenglein AL, Liu W, Thiboutot DM (2008) Neutrophil gelatinase-associated lipocalin mediates 13-cis retinoic acid-induced apoptosis of human sebaceous gland cells. J Clin Invest 118:1468-1478.

Oka M, Fagan KA, Jones PL, McMurtry IF (2008) Therapeutic potential of RhoA/Rho kinase inhibitors in pulmonary hypertension. Br J Pharmacol 155:444-454.

Osmani N, Vitale N, Borg JP, Etienne-Manneville S (2006) Scrib controls $\mathrm{Cdc} 42$ localization and activity to promote cell polarization during astrocyte migration. Curr Biol 16:2395-2405.

Park HC, Boyce J, Shin J, Appel B (2005) Oligodendrocyte specification in zebrafish requires notch-regulated cyclin-dependent kinase inhibitor function. J Neurosci 25:6836-6844.

Pekny M, Nilsson M (2005) Astrocyte activation and reactive gliosis. Glia 50:427-434.

Pellegrin S, Mellor H (2007) Actin stress fibres. J Cell Sci 120:3491-3499.

Raftopoulou M, Hall A (2004) Cell migration: Rho GTPases lead the way. Dev Biol 265:23-32.

Ramakers GJ, Moolenaar WH (1998) Regulation of astrocyte morphology by RhoA and lysophosphatidic acid. Exp Cell Res 245:252-262.

Schmidt-Ott KM, Mori K, Kalandadze A, Li JY, Paragas N, Nicholas T, Devarajan P, Barasch J (2006) Neutrophil gelatinase-associated lipocalinmediated iron traffic in kidney epithelia. Curr Opin Nephrol Hypertens 15:442-449.

Seo MC, Kim S, Kim SH, Zheng LT, Park EK, Lee WH, Suk K (2008) Discoidin domain receptor 1 mediates collagen-induced inflammatory activation of microglia in culture. J Neurosci Res 86:1087-1095.

Sofroniew MV (2005) Reactive astrocytes in neural repair and protection. Neuroscientist 11:400-407.

Son E, Jeong J, Lee J, Jung DY, Cho GJ, Choi WS, Lee MS, Kim SH, Kim IK, Suk K (2005) Sequential induction of heme oxygenase- 1 and manganese superoxide dismutase protects cultured astrocytes against nitric oxide. Biochem Pharmacol 70:590-597.

Stipursky J, Gomes FC (2007) TGF-betal/SMAD signaling induces astrocyte fate commitment in vitro: implications for radial glia development. Glia 55:1023-1033.

Suidan HS, Nobes CD, Hall A, Monard D (1997) Astrocyte spreading in response to thrombin and lysophosphatidic acid is dependent on the Rho GTPase. Glia 21:244-252.

Suk K (2005) Role of caspases in activation-induced cell death of neuroglia. Curr Enzyme Inhib 1:43-50.

Suk K, Lee J, Hur J, Kim YS, Lee M, Cha S, Yeou Kim S, Kim H (2001) Activation-induced cell death of rat astrocytes. Brain Res 900:342-347.

Suk K, Kim SY, Kim H (2002) Essential role of caspase-11 in activationinduced cell death of rat astrocytes. J Neurochem 80:230-238.

Takai Y, Sasaki T, Matozaki T (2001) Small GTP-binding proteins. Physiol Rev 81:153-208.

Takuma K, Baba A, Matsuda T (2004) Astrocyte apoptosis: implications for neuroprotection. Prog Neurobiol 72:111-127.

Tong Z, Wu X, Kehrer JP (2003) Increased expression of the lipocalin 24p3 as an apoptotic mechanism for MK886. Biochem J 372:203-210.

Tong Z, Wu X, Ovcharenko D, Zhu J, Chen CS, Kehrer JP (2005) Neutrophil gelatinase-associated lipocalin as a survival factor. Biochem J 391:441-448.

Trendelenburg G, Prass K, Priller J, Kapinya K, Polley A, Muselmann C, Ruscher K, Kannbley U, Schmitt AO, Castell S, Wiegand F, Meisel A, Rosenthal A, Dirnagl U (2002) Serial analysis of gene expression identifies metallothionein-II as major neuroprotective gene in mouse focal cerebral ischemia. J Neurosci 22:5879-5888.

Trevarrow B, Marks DL, Kimmel CB (1990) Organization of hindbrain segments in the zebrafish embryo. Neuron 4:669-679.

Villefranc JA, Amigo J, Lawson ND (2007) Gateway compatible vectors for analysis of gene function in the zebrafish. Dev Dyn 236:3077-3087.

Wilhelmsson U, Li L, Pekna M, Berthold CH, Blom S, Eliasson C, Renner O, Bushong E, Ellisman M, Morgan TE, Pekny M (2004) Absence of glial fibrillary acidic protein and vimentin prevents hypertrophy of astrocytic processes and improves post-traumatic regeneration. J Neurosci 24:5016-5021.

Wilhelmsson U, Bushong EA, Price DL, Smarr BL, Phung V, Terada M, Ellisman MH, Pekny M (2006) Redefining the concept of reactive astrocytes as cells that remain within their unique domains upon reaction to injury. Proc Natl Acad Sci U S A 103:17513-17518.

Yan QW, Yang Q, Mody N, Graham TE, Hsu CH, Xu Z, Houstis NE, Kahn BB, Rosen ED (2007) The adipokine lipocalin 2 is regulated by obesity and promotes insulin resistance. Diabetes 56:2533-2540.

Yang J, Goetz D, Li JY, Wang W, Mori K, Setlik D, Du T, Erdjument-Bromage H, Tempst P, Strong R, Barasch J (2002) An iron delivery pathway mediated by a lipocalin. Mol Cell 10:1045-1056.

Yoon HJ, Jeon SB, Suk K, Choi DK, Hong YJ, Park EJ (2008) Contribution of TLR2 to the initiation of ganglioside-triggered inflammatory signaling. Mol Cells 25:99-104.

Yousefi S, Simon HU (2002) Granulocyte apoptosis: death by a secreted lipocalin? Cell Death Differ 9:595-597. 